\title{
DILEMAS CONSTITUCIONAIS SOBRE O INÍCIO E O FINAL DA VIDA: UM PANORAMA DO ESTADO DA ARTE NO DIREITO BRASILEIRO'

\author{
BEGINNING AND END OF LIFE: A MAP OF BRAZILIAN CONSTITUTIONAL \\ CHOICES
}

Letícia de Campos Velho Martel

\begin{abstract}
O objetivo que o guiava não era impossível, ainda que sobrenatural. Queria sonhar um homem: queria sonhá-lo com integridade minuciosa e impô-lo à realidade. Esse projeto mágico esgotara o inteiro espaço de sua alma; se alguém lhe perguntasse o próprio nome ou qualquer traço de sua vida anterior, não teria acertado na resposta [...] Temeu que seu filho meditasse nesse privilégio anormal e descobrisse de alguma maneira sua condição de mero simulacro. Não ser um homem, ser a projeção do sonho de outro homem, que humilhação incomparável, que vertigem! A todo pai interessam os filhos que procriou (que permitiu) numa simples confusão ou felicidade; é natural que o mago temesse pelo futuro daquele filho, pensado entranha por entranha e traço por traço, em mil e uma noites secretas [...] O final de suas cavilações foi brusco, mas o anunciaram alguns sinais. Primeiro (no término de uma longa seca) uma remota nuvem numa colina, leve como um pássaro; logo, para o Sul, o céu que tinha a cor rosa da gengiva dos leopardos; depois as fumaradas que enferrujam o metal das noites; depois a fuga pânica das bestas. Porque se repetiu o acontecido faz muitos séculos. As ruínas do santuário do deus do fogo foram destruídas pelo fogo. Numa alvorada sem pássaros, o mago viu cingir-se contra os muros o incêndio concêntrico. Por um instante, pensou refugiar-se nas águas, mas em seguida compreendeu que a morte vinha coroar sua velhice e absolvê-lo dos trabalhos. Caminhou contra as línguas de fogo. Estas não morderam sua carne,

estas o acariciaram e o inundaram sem calor e sem combustão. Com alívio, com humilhação, com terror, compreendeu que ele também era uma aparência, que outro o estava sonhando. (BORGES, 1999).
\end{abstract}

Resumo: O objetivo nuclear do artigo foi traçar um panorama da dimensão vertical do direito fundamental à vida no direito constitucional brasileiro, atendendo à seguinte indagação: qual é o tratamento jurídico atual endereçado aos estágios inicial e final da vida humana? Para tanto, o artigo está dividido em três seções. Na primeira, são expostas as bases conceituais, com especial atenção à estrutura analítica do direito fundamental à vida, às posições subjetivas que lhe são típicas, bem como às suas características de aplicação. $\mathrm{Na}$ segunda, são descritas as questões sobre as etapas iniciais do processo de viver humano e é discutida a titularidade do direito à vida por embriões criopreservados, embriões in útero e fetos, à luz das paradigmáticas decisões do Supremo Tribunal Federal. Na terceira, apresenta-se e discute-se a morte com intervenção ao ensejo dos enunciados normativos vigentes e decisões judiciais. Cada seção é permeada por notas conclusivas e discussão. Palavras-chave: Direito à vida. Começo da vida. Final da vida.
Abstract: The main goal of this paper is to draw an overview of fundamental right to life in Brazilian constitutional law, attempting to answer the following question: what is the current legal treatment addressed to initial and final stages of human life? Thus, the article is divided into three sections. At first, conceptual foundations are described, with special attention to the right to life analytical framework, its categories of jural relationships, as well as its application characteristics. In the second, the focus lies on the initial stages of human life. So, in the light of Brazilian Supreme Court leading cases, I will discuss if cryopreserved embryos, embryos and fetuses in utero entitle the right to life. In the third, the legal norms, including normative acts from the federal administration, dealing with the end of life issues are analyzed. Each section is accompanied by discussion and conclusions.

Keywords: Right to life. Beginning of life. End of life.

\footnotetext{
"Pós-doutoranda em Direitos Fundamentais pela Pontifícia Universidade Católica do Rio Grande do Sul; Doutora em Direito Público pela Universidade Estadual do Rio de Janeiro; Professora da Pontifícia Universidade Católica do Rio de Janeiro; camposvelho@gmail.com

1 Texto originalmente publicado em Clève e Freire (2014, p. 615-654). A seção inicial está em textos outros da autora, incluindo sua tese de doutoramento.
} 


\section{Introdução}

Direito fundamental à vida. A expressão parece autoevidente. É intuitivo pensar que os sistemas constitucionais, desde a sua afirmação liberal-burguesa, consagram e protegem a vida humana em patamar de jusfundamentalidade, guardando, de início, um espaço para debates sobre a legitimidade da pena de morte e a criminalização do suicídio. Todavia, o longo século XX lançou espessa neblina sobre o autoevidente e sobre as intuitivas noções de força e grande proteção do direito à vida. As guerras, com seu típico descarte de milhões de existências, bem como as políticas de desvalorização e de não qualificação de vidas humanas ao sabor características, como a doença mental, a deficiência, a raça, a etnia, a nacionalidade, a sexualidade e a postura política, trouxeram a lume as fragilidades, ambiguidades e paradoxos daquele que parecia ser o menos contestável e duvidoso dos direitos. Inseriram-se no debate a guerra, o genocídio, as execuções e os desaparecimentos forçados, a tortura, bem como a eliminação de indivíduos cujas vidas, de um ponto de vista externo, eram valoradas como indignas de serem vividas. De tão óbvio que parecia, muitas Constituições sequer o expressavam diretamente. Foi apenas nos idos da década de 1940 que a positivação em diversas Constituições ocidentais aconteceu. Houve internacionalização da proteção. Incrementados foram os mecanismos de salvaguarda, assim como as discussões sobre a chamada dimensão horizontal do direito à vida, ou seja, sobre "as facetas sociais" aliadas ao direito fundamental à vida. ${ }^{1}$

Foi mesmo longo o século XX. Paralelamente às narrativas da tragédia causada por humanas mãos, houve narrativas de otimismo nos saberes da saúde, com ampliação do tempo e da qualidade de vida, curas, contorno de sintomatologias, prevenção acentuada, entre outros avanços biotecnológicos. Novos desafios à compreensão do direito fundamental à vida. Vieses competidores apresentam-se, sacralidade versus qualidade da vida. Outras leituras para o velho direito, até um direito antítese. Direito à vida digna. Direito à vida com qualidade. Direito à vida saudável. Direito de nascer. Direito de morrer. Direito de não ter nascido. Proliferam-se as denominações, os significados e os conteúdos. Nada menos autoevidente, nada menos autoexplicativo do que as indagações sobre o momento em que o estágio inicial da vida humana deve ser protegido pelo direito; sobre o status jurídico a ser conferido aos embriões criopreservados e aos fetos; ou sobre o momento em que a vida humana é finalizada, se deve ser perpetuada com o uso de todas as tecnologias em saúde, ou se deve ser permitido ao titular do direito dele dispor ou, ainda, se razoável às

\footnotetext{
1 A distinção entre dimensão horizontal e vertical é formulada por Ramos (2009, p. 223): "A dimensão vertical envolve a proteção da vida nas diferentes fases do desenvolvimento humano (da fecundação à morte). Algumas definições sobre o direito à vida refletem essa dimensão, pois esse direito consistiria no 'direito à não interrupção dos processos vitais do titular mediante intervenção de terceiros e, principalmente, das autoridades estatais'. Há ainda a sua dimensão horizontal, que engloba a qualidade da vida gozada e suas facetas sociais, o que nos leva a discussões sobre a vida digna e sobre o mínimo existencial. Esta dimensão horizontal leva a promoção do direito à vida a abarcar a tutela à saúde, educação, prestações de seguridade social e até mesmo meio ambiente equilibrado."
} 
políticas públicas em saúde obstar tratamentos de final de vida quando muito custosos e de ínfima ou nenhuma eficácia. As biotecnologias abriram uma miríade de perquirições quanto à dimensão vertical do direito fundamental à vida.

No conjunto formado pelas dimensões vertical e horizontal há conteúdos inesgotáveis, que admitem uma plêiade de horizontes teóricos e de ângulos de observação. ${ }^{2}$ Neste artigo existem recortes definidos. O ponto nodal está na dimensão vertical do direito fundamental à vida, com ênfase ao estado da arte do direito constitucional brasileiro acerca do início e do final da vida humana. O norte é oferecido pelos casos judiciais paradigmáticos, bem como pelos enunciados normativos inovadores na temática. A abordagem é essencialmente descritiva e jurídica. Para realizá-la, será examinado o problema da titularidade do direito fundamental à vida, com ênfase para os embriões extranumerários criopreservados, os fetos e os animais não humanos. Após, será considerado o tratamento que o direito brasileiro dispensa à morte com intervenção.

Antes de expor o panorama constitucional pátrio sobre o direito fundamental à vida no que se refere aos dilemas e conflitos jurídicos do início e do final da vida, entende-se pertinente apresentar a dogmática do direito à vida. Serão explorados três planos, o analítico, o de justificação e o de aplicação. No primeiro, serão mapeadas as posições subjetivas básicas do direito. No segundo, a sua importância intrínseca e instrumental no conjunto dos direitos fundamentais. No terceiro, discutir-se-ão as afirmações de que se trata de um direito hierarquicamente superior e de que suas posições subjetivas são absolutas, no sentido de não admitirem qualquer interferência, quer autônoma, quer heterônoma. ${ }^{3}$

O apoio em três planos - analítico, de justificação e de aplicação - encontra sua base teórica em Robert Alexy, especialmente na obra Teoria dos Direitos Fundamentais. Aceita-se que existe possibilidade, eminentemente didática, de separar os três planos. No entanto, de modo algum se sustenta que não sejam interligados e que não exerçam influência recíproca. Reconhece-se como predominante no direito constitucional brasileiro a teoria externa dos direitos fundamentais, bem como a aplicação do postulado da proporcionalidade. ${ }^{4}$

Tanto a arquitetura dos argumentos sobre o direito à vida quanto as reflexões sobre os julgados e enunciados normativos serão formuladas considerando-se os três planos do direito fundamental à vida combinados ao ideal de integridade dworkiniano. Ou seja, pretende-se, por um viés reconstrutivista, interpretar o orde-

\footnotetext{
2 Considera-se relevante consultar York (2010, p. 1-36).

3 O trecho inicial corresponde ao de publicações anteriores. As descrições e análises que seguem, sobre a titularidade, o início e o final da vida, foram elaboradas exclusivamente para este texto.

4 É sabido que as teorias variam entre si, bem como são objetos de diversas críticas. Aqui, adota-se a teoria em sua vertente alexyana, no estilo de um tipo-ideal.
} 
namento jurídico como um todo, à sua melhor luz, buscando a teia inconsútil que lhe ofereça coerência de princípios. ${ }^{5}$

\section{0 direito fundamental à vida: um velho (des)conhecido}

O direito à vida, um dos componentes da tríade lockeana, figurou já nas primeiras Cartas e Declarações de Direitos modernas, como a Declaração de Direitos da Virgínia, a Declaração de Direitos da Constituição dos Estados Unidos da América e em muitas mais (THE CHARTERS OF FREEDOM, 1776, 1791; COMPARATO, 2003; SCHWARTZ, 1979). ${ }^{6}$ Em virtude da sua época e modos de afirmação, o direito é exposto, pela doutrina, como de primeira geração ou de primeira dimensão, ao lado das liberdades, da segurança individual e da propriedade (MARSHAL, 1967; BOBBIO, 1992, SARLET, 2001, p. 38 e ss). ${ }^{7}$ Nas décadas que se seguiram às chamadas declarações e constituições burguesas, houve sérios trabalhos sobre o direito à vida, especialmente acerca da pena de morte e da punição civil e criminal do suicídio, na pessoa do suicida (se tentado) ou de seus familiares. ${ }^{8}$

Nas constituições vigentes e nas declarações e pactos internacionais contemporâneos, típicos do período posterior à Segunda Grande Guerra, o direito à vida foi notadamente expresso e ganhou fortalecimento jurídico-moral diante dos nefastos acontecimentos que permearam o século XX, como o holocausto, a construção de conceitos heterônomos de vidas indignas de serem vividas e a emergência dos totalitarismos e das ditaduras. A proteção e a valorização da vida humana tornaram-se ainda mais proeminentes, levando o direito à vida a assumir uma relevância ímpar nas sociedades políticas ocidentais. Tanto é que há quem repute a vida humana como um bem de valor intrínseco. A noção traslada-se para o ambiente jurídico, traduzindo-se na intensa proteção, defesa e promoção do direito à vida como um

\footnotetext{
5 Com isso, não se afirma que Dworkin e Alexy tenham a mesma postura acerca da aplicação dos princípios. Entende-se que Dworkin não abalizaria a proporcionalidade, mas afirma-se que a noção de integridade pode ser empregada para oferecer sólidas bases para o melhor emprego da proporcionalidade.

6 Nem todos os estudiodos concordam com essa perspectiva. Para os que discordam, o direito à vida ganhou alçada constitucional relevante apenas após a Segunda Guerra Mundial, muito em razão da permissão da pena de morte. Todavia, entende-se inegável que as primeiras declarações de direitos da modernidade já traziam o direito à vida, assim como a teoria de base, os jusnaturalistas do século XVIII, valoravam-no e assumiam a sua importância, daí a famosa tríade lockeana, vida, propriedade e liberdade. Nas Constituições brasileiras, as de 1824 e de 1891 , não enunciaram expressamente o direito à vida, embora a última tenha abolido a pena de morte em tempos de paz. No mesmo sentido da Constituição de 1891, a de 1934. A Carta de 1937 também não previu expressamente o direito e alargou hipóteses de instituição de pena de morte em tempos de paz (art. 122, 13). A Constituição de 1946 foi a primeira a positivar o direito à vida, no caput do art. 141: "Art 141 - A Constituição assegura aos brasileiros e aos estrangeiros residentes no País a inviolabilidade dos direitos concernentes à vida, à liberdade, à segurança individual e à propriedade, nos termos seguintes [...]", dicção que foi reproduzida na Carta de 1967 e se assemelha ao caput do art. $5^{\circ}$ da Constituição vigente (CHUECA, 2009, p. 99-123). Os textos constitucionais, com exceção do de 1988, foram pesquisados em: Brasil (2001) e Pacheco (1958-1965).

7 Ao mencionar que o direito é classificado como de primeira dimensão, não se afirma que seja exclusivamente um direito de defesa ou negativo, tampouco se adere à ideia de que os direitos de primeira dimensão são os que demandam exclusivamente uma omissão estatal. A noção de primeira dimensão refere-se, aqui, muito mais ao momento de reconhecimento jurídico e às necessidades às quais tal reconhecimento pretendeu atender inicialmente. Nesse sentido, tem-se em mente a releitura de Holmes e Sunstein (2000, p. 13-48).

8 Sobre o tema, ver Dowbiggin (2005, p. 30 e ss).
} 
todo, tanto em seus feixes de posições subjetivas quanto em sua dimensão objetiva. ${ }^{9}$ Entende-se tratar-se de um consenso político robusto, que pode ser vertido na linguagem da dignidade humana como heteronomia, que teria uma das suas manifestações na intensa valorização da vida humana e consequente diferenciação do direito à vida frente aos demais direitos. ${ }^{10}$

Para além do valor intrínseco, o bem vida e o direito à vida como um todo possuem um caráter instrumental sui generis. A própria titularidade dos direitos fundamentais e também da dignidade humana depende do bem vida e do direito à vida. Ao perecer a vida humana, ausente estará a titularidade dos outros direitos. Nesse mesmo sentido, o enfraquecimento de posições subjetivas e também da dimensão objetiva do direito à vida ocasiona densos reflexos em todas as posições subjetivas de direitos fundamentais, levando-as, não raras vezes, à extinção.

Pelo exposto, sequer é preciso discutir a jusfundamentalidade material e formal do direito à vida. Trata-se, é notório, de um direito fundamental. E de um direito fundamental especialíssimo e muito delicado. Ademais, é direito fundamental ubíquo, que permeia os mais diversos ramos do direito e, também por esse motivo, vincula particulares em variados contextos. Tamanha é a importância a ele conferida, que não é difícil encontrar referência sobre ser ele o primeiro, o mais importante dos direitos fundamentais, o direito fundamental, o qual, por si, já assume um peso abstrato mais elevado em casos de ponderação, ou expressões no sentido de que "[...] no right is more fundamental than the right to life." (BEYLEVELD; BROWNSWORD, 2004, p. 285). ${ }^{11}$ Essas pertinentes afirmações estão por ocasiões atreladas, na doutrina e até na jurisprudência brasileiras, à conferência de um cunho absoluto às posições subjetivas do direito e à sua dimensão objetiva, bem como à categorização do direito como de maior hierarquia em relação a todos os demais direitos fundamentais e princípios constitucionais. Os posicionamentos são muito fortes e merecem esclarecimentos e tomada de posição. Antes de adentrar no tema, atinente ao plano de aplicação, é prudente compreender a estrutura básica do direito à vida.

\subsection{A estrutura básica do direito à vida}

Os direitos fundamentais são compostos por duas dimensões, a subjetiva e a objetiva. A soma das duas dimensões forma o chamado direito fundamental como um todo. Com o direito à vida não é diferente. A meta desta seção é pôr às claras o feixe

\footnotetext{
9 Sobre o valor intrínseco da vida humana, mesmo a par da dificuldade em sustentar que algo possui valor intrínseco nas sociedades atuais, ver Dworkin (2003, p. 95-140).

10 Sobre o conceito de dignidade como heteronomia, entendida como valores sociais que podem ser impostos aos indivíduos e moldar seus direitos de liberdade a partir de um prisma externo, ver Beyleveld e Brownsword (2004), Martel (2004, 2010) e Barroso (2012).

${ }^{11}$ No caso Pretty, a Corte Europeia de Direitos Humanos foi muito clara sobre a proeminência do direito à vida. Na doutrina brasileira, ver Bulos (2007). Também o Ministro Marco Aurélio, em voto proferido na década de 1990, acerca da competência em atos considerados genocídio de populações indígenas: "Não há, no dispositivo, qualquer restrição a estes últimos, a envolver, sem dúvida alguma, o bem maior, que é a própria vida.” (BRASIL, 1994).
} 
básico de posições subjetivas do direito à vida e discuti-las, tarefa que se considera inicial ao exame de qualquer direito fundamental. Antes de apresentar as posições subjetivas básicas, alerta-se que se está a seguir a advertência de Joel Feinberg a respeito do direito à vida:

Exatamente que tipo de direito é "o direito à vida"? Numerosas distinções podem ser feitas, é claro, entre os vários tipos e categorias de direitos. Porquanto é impossível aqui trabalhar completamente à nossa maneira nesse labirinto conceitual, será útil esclarecer o direito à vida situando-o em relação às mais importantes dessas distinções. Isso será em parte uma questão de estipulação, pois o direito à vida é interpretado de maneiras diferentes por diferentes autores, e onde há desacordo ou confusão, eu posso apenas tentar fazer sugestões persuasivas de que uma ou outra interpretação é mais padrão, útil ou importante. Eu proponho, antes de tudo, interpretar "o direito à vida" de um modo relativamente estreito, de modo que ele se refere ao "direito de não ser morto" e ao "direito de ser salvo da morte iminente", e não a uma concepção mais ampla, favorecida por muitos autores de manifesto, de um "direito a viver decentemente". Certamente, como Hugo Bedau expõe, "a vida que nós agora consideramos que os homens são titulares como direito não é [meramente] um direito no menor nível suficiente para evitar uma morte prematura; pelo contrário, é uma vida adequada para o autorrespeito, o alívio da labuta desnecessária, e a oportunidade de liberar energia produtiva." Todavia, nós podemos referir separadamente os componentes de um direito a viver decentemente: um direito a condições de trabalho decentes, um direito à alimentação, ao vestuário, à moradia, à educação e assim por diante. (FEINBERG, 1997, p. 224). ${ }^{12}$

Portanto, para apreciar a estrutura do direito à vida, ele será isolado dos demais direitos. Não se nega outros direitos ao adotar esse raciocínio. $\mathrm{O}$ direito à vida é instrumental e está associado, de modo mais ou menos direto, a todos os direitos fundamentais. Ampliar o direito à vida, concebendo-o como direito à vida digna ou, ainda, à vida decente, retira muito a clareza e, em diversas situações, pouco acrescenta ao debate, especialmente no Brasil, cuja Constituição analítica positiva uma gama de direitos sociais, econômicos e culturais, além de trazer em seu bojo menção à dignidade humana. ${ }^{13}$ Compreender a estrutura do direito à vida em separado não leva à

\footnotetext{
12 "Just what kind of right is 'the right to life'? Numerous distinctions can be made, of course, among the many types and categories of rights. While it is impossible here to work our way completely through the conceptual maze, it will be useful to clarify the right to life by placing it in relation to some of the more important of these distinctions. This will be in part a matter of stipulation, for the right to life is interpreted in different ways by different writers, and where there is disagreement or confusion, I can only try to make persuasive suggestions that one or another interpretation is more standard, useful, or important. I propose, first of all, to interpret 'the right to life' in a relatively narrow way, so that it refers to 'the right not to be killed' and 'the right to be rescued from impending death', but not to the broader conception, favored by many manifesto writers, of a 'right to live decently'. To be sure, as Hugo Bedau put it '[...] the life to which we now think men are entitled as of right is not [merely] a right at the barest level sufficient to stave off an untimely death; rather it is a life sufficient for self-respect, relief from needless drudgery, and opportunity for the release of productive energy. However, we can refer separately to the components of a right to live decently: a right to decent working conditions, a right to food, to clothing, to housing, to education, and so on."

13 O direito à vida, como os demais direitos fundamentais, tem a marca da historicidade e, como princípio, da plasticidade. É por isso que se usou a palavra básicas para designar as posições subjetivas ora explanadas. Para os temas em estudo, as posições básicas são suficientes. Porém, não estão excluídas outras posições, acrescidas para responder a novos problemas ou concepções, elemento comum na interpretação e aplicação dos direitos fundamentais. Por exemplo, em questões envolvendo o desenvolvimento científico sobre manipulação genética, diagnósticos
} 
afirmação de que sua atuação e interpretação são insulares. Em muitas situações, outros direitos também estarão em cena. Mas são outros direitos. Corroboram com esse pensar dois cânones de interpretação da Constituição, a noção de que o constituinte não emprega palavras de modo inútil (o que aconteceria se o direito à vida encampasse outros direitos e princípios expressos, como a saúde, a dignidade e as condições de trabalho) e também a impossibilidade de se interpretar o texto de modo desintegrado e hiperintegrado. ${ }^{14}$ Ademais, o foco da seção está na dimensão vertical do direito à vida, que pode ser mais bem explorada se ele estiver em apartado.

Quais posições subjetivas possui o direito à vida? McConnell (2000) indica que há pelo menos duas interpretações competidoras sobre as posições subjetivas do direito à vida, uma que ele denomina interpretação negativa e a outra, interpretação positiva. Na primeira, inclui-se no direito à vida apenas as posições subjetivas que impõem o dever de não matar (correlato ao direito estrito de não ser morto). $\mathrm{Na}$ segunda, além das posições reconhecidas pela primeira, posições que impõem deveres de salvar os titulares da morte e de não abandoná-los à morte (correlatos ao direito estrito de ser salvo de morte iminente) (MCCONNELL, 2000, p. 79-80). Feinberg (1997, p. 224-225) é enfático ao afirmar que se trata de um direito estrito (claim-right), com, no mínimo, duas posições, a de não ser morto e a de não ser abandonado à morte. ${ }^{15}$ Beyleveld e Brownsword (2007) estruturam as posições subjetivas do direito à vida também como direitos estritos, esmiuçando-as adequadamente:

DV(a): um direito estrito negativo de que outros indivíduos não se comportem de formas direcionadas a pôr fim à vida de alguém (i.e., o direito básico, possivelmente estendido para cobrir condutas negligentes e imprudentes) $;{ }^{16}$ DV(b): um direito estrito negativo de que outros indivíduos não tomem medidas para assistir a outros a pôr fim à vida de alguém ou a assistir alguém a pôr fim à própria vida;

DV(c): um direito estrito positivo de que outros indivíduos comportem-se segundo formas designadas a salvar ou manter a vida de alguém;

DV(d): um direito estrito positivo de que outros indivíduos comportem-se de tal forma que auxiliem no salvamento ou na manutenção da vida de alguém. (BEYLEVELD; BROWNSWORD, 2007, p. 274). ${ }^{17}$

Acertadamente, os autores mostram que a cada posição corresponde um dever, seja o de não realizar o ato de matar ou de abster-se de auxiliar alguém a morrer,

\footnotetext{
embrionários, clonagem, outras posições poderão ser aventadas e aceitas, inclusive sob um enfoque menos individual. Sobre a historicidade, ver Bobbio (1992) e Canotilho ([entre 1997 e 2012], p. 1087).

${ }_{14}$ As formulações desintegrada e hiperintegrada são empregadas por Tribe para cognominar dois modos de não ler uma Constituição (TRIBE, 1991, p. 19 e ss).

15 Alexy (1993, p. 187-188) situa como posição subjetiva do direito à vida, a de não ser morto arbitrariamente.

16 Nesse ponto, acrescenta-se a noção do direito estrito à não eliminação da situação jurídica de estar vivo por parte do Estado. Sobre o tema ver Alexy (1993, p. 187-188).

17 " $R L(a)$ : a negative claim-right that other agents do not act in ways that are intended to terminate one's life (ie the basic right, possibly extended to cover reckless and careless conduct); $R L(b):$ a negative claim-right that others agents do not take steps to assist others to terminate one's life or to assist one to terminate one's life; RL(c): a positive claimright that other agents act in ways that are designed to save or sustain one's life; $R L(d)$ : a positive claim-right that other agents act in such a way as to assist in saving or sustaining one's life."
} 
seja o de salvar ou de auxiliar no salvamento de alguém. Nas posições mencionadas, o sujeito passivo poderá ser tanto o Estado (em sentido amplo) quanto os particulares. Tomado em sua estrutura de direito fundamental, o direito à vida traz consigo ainda outras posições subjetivas endereçadas somente ao Estado, a saber: DV(e): direito à não eliminação das posições jurídicas do direito à vida, que se manifesta como imunidade com a correlata não competência; DV(f): direito estrito a ações positivas fáticas; DV(g): direito estrito a ações positivas normativas (ALEXY, 1993, p. 187-188; HOHFELD, 2000; MARTEL, 2010, p. 40-59).

A titularidade de tais posições subjetivas é, ao menos, de todos os seres humanos nascidos vivos, havendo espaço para discutir quais outros entes são titulares, como embriões, fetos e animais não humanos. No direito brasileiro, existe tendência à teoria dos direitos subjetivos como interesse, em oposição à teoria dos direitos subjetivos como vontade. Por isso, para a definição dos titulares de um direito fundamental, não se faz necessário determinar a habilidade jurídica para exercer o direito, mas apenas o reconhecimento de um interesse a ser juridicamente protegido. A identificação do interesse ocorrerá mediante procedimentos democráticos, com pauta nos direitos fundamentais, na textualidade dos enunciados normativos e normas daí advindas, bem como pela interpretação do sistema à luz da integridade.

As discussões sobre a titularidade do direito à vida estão mais ligadas aos problemas jurídicos relativos ao início da vida humana (fetos, embriões) e aos animais não humanos. Reconhecer um ente vivo como titular do direito fundamental à vida significa, no ordenamento brasileiro, conferir status de pessoa. Todavia, o elemento "ser vivo" não é suficiente para a titularidade do direito à vida, pois não há correspondência direta entre os preceitos de ramos das ciências biológicas e da saúde - cujos critérios de validação discursiva e paradigmática são próprios e orientados a finalidades específicas -, e o sistema jurídico, que tem sua validação na democracia e nos direitos fundamentais. Em assim sendo, se a biologia afirma que um beagle é um ser vivo, disso não se deduz que os beagles sejam titulares do direito fundamental à vida. Na mesma senda, da afirmação de que um embrião humano está vivo, não se infere, pelo mesmo critério de verificação, que o embrião humano seja, necessariamente, titular do direito fundamental à vida. A titularidade do direito fundamental à vida não é determinada por campos normativos das ciências da saúde, mas é definida segundo critérios típicos do direito, campo normativo distinto, que pode se comunicar com e utilizar os resultados científicos, mas pode, até mesmo, recusá-los..$^{18}$

Quanto à terminalidade da vida e à morte com intervenção, não é usual a argumentação de que os seres humanos em final de vida não sejam titulares do direito à vida, tampouco é corrente a noção de que a titularidade do direito à vida resta enfraquecida ou se desfaz ao ensejo da qualidade, da dignidade ou do tempo de

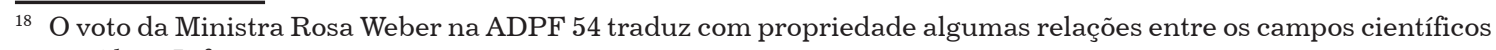
e o jurídico. Infra. 
sobrevida. Portanto, não se debate com intensidade se enfermos terminais, pessoas em estado vegetativo persistente ou com síndrome do encarceramento são titulares do direito à vida. É tradicional e representa um forte consenso a ideia de que a qualidade da vida ou a dignidade da vida dos seres humanos, vistas aos olhos de terceiros (i.e., heteronomamente), são desimportantes para a manutenção da titularidade das posições. Condições altamente adversas, em seres humanos nascidos com vida, não ensejam perda da titularidade de posições subjetivas do direito à vida. ${ }^{19}$ Indivíduos muito enfermos, terminais, portadores de doenças degenerativas gravíssimas, de transtornos mentais acentuados, de deficiências físicas significativas, de moléstias transmissíveis, em estado comatoso ou vegetativo persistente e tantos mais são tão titulares das posições subjetivas do direito à vida e abarcados pela sua dimensão objetiva quanto indivíduos saudáveis e produtivos. As condições adversas não são suficientes para retirar a titularidade. Ao contrário, indivíduos em condições adversas de vida normalmente compõem grupos especialmente vulneráveis e invisibilizados, gerando assimetria nas relações que com eles são travadas.

\subsection{Direito à vida e suas distintivas características de aplicação}

Páginas atrás, foi mencionado que esporadicamente se encontram afirmações de que o direito à vida é um direito absoluto, dotado de superior hierarquia. Se assim for, trata-se de um direito que não admite qualquer restrição (heterônoma) e que não será objeto de ponderação, uma vez que a técnica somente faz sentido quando os enunciados normativos possuem a mesma hierarquia. Portanto, não se admitiriam enfraquecimentos heterônomos nos deveres correlatos às posições subjetivas do direito à vida ancorados em outros princípios ou direitos. ${ }^{20}$

Tome-se, em primeiro lugar, a afirmação de que o direito à vida é absoluto. Ela significa que se trata de um direito imune a qualquer interferência, que não admite restrições e que não há ponderação hábil a justificá-las. Considerada ao ensejo da teoria interna dos direitos fundamentais, a afirmação guarda sentido e razão de ser. ${ }^{21}$ Entretanto, ao adotar a teoria externa, combinada ao suporte fático amplo dos direitos fundamentais, a afirmação contradiz um ponto básico da teoria: os direitos fundamentais, como princípios, são prima facie restringíveis. Teoricamente, portanto, todos os direitos fundamentais, ou pelo menos quase todos, são restringíveis.

\footnotetext{
19 Fica em aberto, ocasionando dilemas e conflitos bioéticos, a situação dos neonatos (bebês nascidos com vida) muito prematuros e que não preenchem as características básicas para o investimento médico, isto é, situam-se na fronteira entre a pesquisa e a assistência, no limite entre a não maleficência e a beneficência, uma vez que as suas chances de vida, suas dores e a intensidade das sequelas são pouco conhecidas e pouco previsíveis.

20 A restrição de uma posição subjetiva de direito fundamental é heterônoma, isto é, externa. A autolimitação e a disposição são autônomas, ou seja, justificam-se mediante manifestação da liberdade do titular. No ponto ver Martel (2010, p. 60-84).

${ }^{21}$ A teoria interna dos direitos fundamentais caracteriza-se por negar a possibilidade de restrições aos direitos. Logo, todos os direitos são absolutos e a técnica para solução de antinomias não é a ponderação. A respeito, ver Pereira (2006) e Silva (2004).
} 
No Brasil, há inúmeras manifestações em decisões judiciais e em votos de Ministros dos Tribunais Superiores, do STF inclusive, além de menções doutrinárias, afirmando que a Constituição de 1988 não alberga direitos absolutos..$^{22}$ De outro lado, é possível encontrar, aqui e acolá, algumas referências acerca do caráter absoluto do direito à vida..$^{23}$ Seria então o direito à vida um dos raros direitos absolutos, à luz da teoria externa? É preciso verificar o sistema jurídico nacional nos moldes da integridade e da coerência para responder à pergunta.

O texto constitucional brasileiro menciona, expressamente, ao menos uma possibilidade de restrição ao direito à vida, ao permitir a instituição da pena de morte em caso de guerra declarada. ${ }^{24} \mathrm{E}$ também em enunciados normativos infraconstitucionais se encontra a moderada admissão de intervenções com o direito à vida, em suas posições subjetivas, considerando-se a aceitação da legítima defesa e do estado de necessidade. São exemplos de intervenções não expressamente autorizadas pela Constituição, mas reputadas plausíveis e cuja constitucionalidade ou recepção não foi alvo de contendas. Poder-se-ia objetar dizendo que tanto na legítima defesa quanto no estado de necessidade estariam em causa posições subjetivas do direito à vida de titularidade diversa. Ora, ainda que sejam as mesmas posições, do argumento não se deduz que o direito à vida seja absoluto; ao contrário, ele demonstra que, em concorrendo as mesmas posições subjetivas do direito à vida de diferentes titulares, o legislador ponderou e conferiu maior peso a uma delas, tornando permissível a interferência com a outra. Acresça-se que a legítima defesa e o estado de necessidade não se aplicam apenas aos casos em que estão em liça posições subjetivas do direito à vida. Suponha-se que uma mulher, ao ser estuprada e agredida, sem ser ameaçada de morte e mediante promessa de que não será morta, reaja e acabe por matar o agressor. É perfeitamente possível que o ato de matar tenha acontecido em legítima defesa (desde que presentes seus requisitos) e constitua comportamento escusável. Aqui, tem-se uma ponderação legislativa e/ou

\footnotetext{
${ }_{22}$ Nesse sentido, ver Mendes et al. (2007). No Supremo Tribunal Federal, a título exemplificativo: Na ementa de um Mandado de Segurança, decidido pelo Tribunal Pleno no final da década de 1990, lê-se: "OS DIREITOS E GARANTIAS INDIVIDUAIS NÃO TÊM CARÁTER ABSOLUTO. Não há, no sistema constitucional brasileiro, direitos ou garantias que se revistam de caráter absoluto, mesmo porque razóes de relevante interesse público ou exigências derivadas do princípio de convivência das liberdades legitimam, ainda que excepcionalmente, a adoção, por parte dos órgãos estatais, de medidas restritivas das prerrogativas individuais ou coletivas, desde que respeitados os termos estabelecidos pela própria Constituição. O estatuto constitucional das liberdades públicas, ao delinear o regime jurídico a que estas estão sujeitas - e considerado o substrato ético que as informa - permite que sobre elas incidam limitações de ordem jurídica, destinadas, de um lado, a proteger a integridade do interesse social e, de outro, a assegurar a coexistência harmoniosa das liberdades, pois nenhum direito ou garantia pode ser exercido em detrimento da ordem pública ou com desrespeito aos direitos e garantias de terceiros." (BRASIL, 2000). Um pouco mais recentes, as afirmações dos Ministros Peluso e Celso de Mello, respectivamente: "Todos os direitos o são, essa é a verdade. Não há nenhum de caráter absoluto." "É certo que o direito de crítica não assume caráter absoluto, eis que inexistem, em nosso sistema constitucional, como reiteradamente proclamado por esta Suprema Corte (RTJ 173/805810 807-808, v.g), direitos e garantias revestidos de natureza absoluta." (BRASIL, 2009, grifo nosso). Especificamente sobre não ser o direito à vida absoluto, ver Brasil (2006).

${ }^{23}$ Porém, muitas soam como simples dicta, um reforço argumentativo que convive com manifestações, dos mesmos Tribunais, Turmas e até julgadores, de que não há direitos absolutos. Ilustrativamente: Rio Grande do Sul (2005, 2000) e Brasil (2009).

${ }^{24}$ É a interpretação combinada dos arts. $5^{\circ}$, XLVII, a, e 84, XIX, ambos da Constituição Federal.
} 
judicial que torna permissível uma agressão a posições subjetivas do direito à vida em nome de posições subjetivas de outros direitos. ${ }^{25}$

Os singelos exemplos já são suficientes para indicar que as posições subjetivas do direito à vida não são absolutas. Admite-se, portanto, que elas estejam sujeitas a restrições. Porém, ressalta-se que as admitir não significa igualar de plano as posições subjetivas do direito à vida às de todo e qualquer direito fundamental. $\mathrm{O}$ direito à vida é especial. $\mathrm{O}$ bem por ele protegido é diferenciado. $\mathrm{O}$ direito à vida precisa de muito zelo e de muita cautela quando se trata de discutir o enfraquecimento da sua força jurídica e moral. Qualquer ablação, heterônoma ou autônoma, é delicada. Qualquer desprezo pela vida humana e pelo direito que a protege, mesmo nas circunstâncias mais adversas, é suspeito.

As considerações não são sinônimo de entender que o direito à vida seja absoluto, tampouco que não existam outros direitos que a ele se sobreponham frente a certas condicionantes, muito menos que a dignidade humana comporte exclusivamente a proteção e a promoção do direito à vida. Interpretando o sistema jurídico brasileiro à luz da integridade, percebem-se outros elementos que indicam que tais sustentações não são compossíveis. Fosse absoluto o direito à vida, prevalecesse sempre, não haveria justificação para a política brasileira de transplantes de órgãos, pois ela situa a escolha do indivíduo e de sua família acima do direito à vida daqueles que carecem de órgãos. ${ }^{26}$ Fosse absoluto o direito à vida, seria dever estatal ordenar salvamentos, ainda que isso demandasse heroísmo e comportamentos super-rogatórios da generalidade dos indivíduos, habitualmente negados pelos e aos sistemas jurídicos. ${ }^{27}$

Até pouco tempo, não havia menções diretas na jurisprudência do STF, corroborando essa conclusão acerca do direito à vida. Encontravam-se, como referido,

\footnotetext{
25 Sobre a questão, Novais (2003) afirma: "Mesmo o direito à vida - tão frequente quanto inadequadamente invocado como paradigma de valor constitucional supremo e, por isso, insusceptível de qualquer restrição ou ponderação - não escapa a idênticas dificuldades inviabilizadoras de uma aplicação eventualmente esquemática e independente das circunstâncias da sua concretização. Desde logo porque pode haver colisão entre o mesmo direito à vida de diferentes titulares. Mas também porque o contexto em que o conflito deva ser resolvido pode ser tão imprevisto quanto decisivamente marcado pelas aflorações concretas dos direitos em questão." Como faz o autor, cabe lembrar os polêmicos casos sobre a separação cirúrgica de gêmeos coligados, quando há alto risco ou até certeza de que um deles irá perecer. Para um debate sobre os casos, ver: Beyleveld e Brownsword (2007, p. 298 e ss, 2004 , p. 254 e ss). E, ainda, o número especial da Medical Law Review destinado unicamente ao assunto: Medical Law Review (2001, p. 201-298). Acerca das discussões sobre o caráter absoluto do direito à vida, é importante consultar os experimentos mentais de Thomson (1990, p. 135) e de Novais (2003, p. 715 e ss).

26 No Brasil, adota-se um modelo de “consentimento explícito universal restringido" para os transplantes post mortem. Caso fosse absoluto o direito à vida, dever-se-ia adotar um modelo obrigatório ou, pelo menos, um modelo de "consentimento tácito universal absoluto" (esquema jurídico de dissenso). Na legislação nacional, chegou a viger um modelo de dissentimento, mas a polêmica foi tão intensa que ele foi revogado em prol do consentimento expresso. A simples existência do debate público demonstra a importância oferecida ao consentimento no tema, ainda que em jogo o direito à vida. Já os transplantes inter vivos seguem regras estritas, baseadas no consentimento genuíno do doador. Fosse absoluto o direito à vida, ter-se-ia que discutir seriamente os limites do dever de salvar a vida alheia, podendo-se, então, cogitar a doação e a transplantação compulsórias de órgãos, nos casos em que os riscos para o doador não fossem de vida. Sobre o tema, ver López (2001) e Brasil (1997, 2001). A respeito do dever de salvar e a extensão do direito à vida, verificar Mcconnell (2000, p. 79 e ss).

${ }_{27}$ Por super-rogatórios: "Supererogation is the technical term for the class of actions that go 'beyond the call of duty'. Roughly speaking, supererogatory acts are morally good although not (strictly) required." Para uma discussão inicial sobre a categoria: Stanford Encyclopedia of Philosophy (2002).
} 
expressões globais sobre a inexistência de direitos absolutos ou, especificamente, sobre outros direitos. A afirmação foi direcionada ao direito à vida em dois julgados do STF atinentes a controvérsias sobre o início da proteção jurídica à vida humana. $\mathrm{Na}$ ADI 3510, que tratou das pesquisas científicas em células tronco de embriões excedentários criopreservados, a Ministra Cármen Lúcia asseverou:

Violar tem o sentido de infringir com violência, transgredir ou ofender o que é posto pelo direito. A inviolabilidade do direito à vida, que o Procurador-Geral da República põe como estando descumprido pelo art. $5^{\circ}$ e parágrafos da Lei n. 11.105/2005, não pode ser interpretada a partir da ideia de direito absoluto. (BRASIL, 2010).

Na ADPF 54, sobre a antecipação terapêutica do parto de feto portador de anencefalia, o voto do Ministro Relator, Marco Aurélio, conta com subseção intitulada $O$ caráter não absoluto do direito à vida (BRASIL, 2012), tópico mencionado com clareza também por diversos outros votos no julgado. É vigoroso, portanto, o indicador de que o Supremo Tribunal Federal adota a noção de que o direito à vida admite restrições, ainda que excepcionalmente.

Em segundo lugar, atente-se para a afirmação de que o direito à vida conta com hierarquia normativa superior em relação aos demais enunciados normativos constitucionais, quer de direitos fundamentais, quer de metas coletivas. Sugerir um posto hierárquico cimeiro para o direito à vida é distinto de asseverar que ele conta com um peso abstrato maior, ou com uma posição preferencial. Tanto a noção de um peso abstrato maior quanto a doutrina da posição preferencial são ajustáveis à ponderação e levam à admissão de restrições ao direito, desde que existam argumentos muito cogentes, com peso suficiente a justificar a ablação, diante de um escrutínio mais rigoroso. ${ }^{28} \mathrm{Ou}$ seja, nem o maior peso abstrato, nem a posição preferencial significam, tecnicamente, maior hierarquia. Esta é estanque, quer dizer, qualquer enunciado normativo que se contraponha a outro de superior hierarquia sucumbe.

A hierarquização "[...] uno de los métodos a que se recurre-especialmente en la doctrina - para resolver conflictos entre derechos - consiste en establecer entre ellos jerarquías o categorías previas y rígidas." (SERNA; TOLLER, 2000, p. 7). ${ }^{29}$ Assim, os direitos de maior hierarquia sempre prevalecem sobre os de menor. A tese, se amplamente abraçada, não se coaduna à ponderação e à aplicação do postulado da proporcionalidade, remetendo a um método de subsunção. E apresenta outros problemas. O primeiro deles é como estabelecer, à partida, quais direitos ocupam a maior hierarquia. O segundo é que se trata de um método desatento às circunstâncias concretas, provendo respostas preconcebidas para a mais variada gama de situações. O terceiro é que não oferece mecanismos para solucionar eventuais colisões entre posições de mesma hierarquia. No quarto, é que o método insinua a existência de

\footnotetext{
28 Sobre os pesos abstratos diferenciados, ver Martel (2010). Sobre a posição preferencial, verificar Pereira (2006, p. 234 e ss), Schreiber (2008, p. 69 e ss) e Martel (2004, p. 91-117).

${ }^{29}$ Convém aclarar que os autores não adotam a ponderação e a proporcionalidade.
} 
hierarquia entre as próprias normas constitucionais originárias. Se o direito à vida possui maior hierarquia, como conciliá-lo à previsão de pena de morte em caso de guerra declarada ${ }^{30}$ No quinto, é que o método desdiz o reconhecido cânone de unidade da Constituição, pois há hierarquias pré-fixadas, as quais, diga-se, não foram estipuladas pelo Constituinte, mas o são pelos intérpretes e, pior, mediante critérios dissonantes (BARROSO, 2003, p. 196-218; BERCOVICCI, 2000, p. 95-99). No sexto, já alinhavado, é que a hierarquização não se amolda e até nega a proporcionalidade, que conta com aceitação jurisprudencial e doutrinária no Brasil.

O que foi dito acerca do caráter não absoluto do direito à vida pode ser trasladado para a suposta maior hierarquia do direito. O Supremo Tribunal Federal não havia feito referência direta ao assunto até as decisões da ADI 3510 e da ADPF 54, ocasiões nas quais alguns Ministros referiram que o direito à vida não é hierarquicamente superior aos demais. ${ }^{31}$

Diante disso, afigura-se equívoco reputar o direito à vida como sendo absoluto e hierarquicamente superior aos demais. Porém, mantém-se o posicionamento de que, na cultura de direitos das sociedades políticas ocidentais contemporâneas, é razoável sustentar que o direito à vida possui um peso abstrato maior ou que ocupa uma posição preferencial. Ou seja, para que possa ser restringido heteronomamente, é preciso arcar com um robusto ônus argumentativo. Ainda que o STF não tenha expressado esse posicionamento na ADI 3510 ou na ADPF 54, acredita-se que conferir peso abstrato maior ao direito fundamental à vida está em consonância com o sistema jurídico brasileiro, bem como com a tônica de proteção ao direito à vida contida em todos os votos proferidos na ADPF 54.

Feitas as considerações basilares acerca das características de aplicação do direito fundamental à vida, passa-se agora ao exame da sua titularidade no sistema constitucional brasileiro.

\footnotetext{
30 Diz-se insinua, porque é viável construir o método sem que ele implique a aceitação de enunciados normativos constitucionais originários inconstitucionais. O STF rechaçou a possibilidade de declaração de inconstitucionalidade de enunciados normativos constitucionais originários (BRASIL, 1996).

31 No voto do Ministro Marco Aurélio, Relator, há um item versando sobre o caráter não absoluto do direito à vida, no qual ele asseverou não ser o direito dotado de maior hierarquia: " $4.1 \mathrm{O}$ caráter não absoluto do direito à vida. Inexiste hierarquia do direito à vida sobre os demais direitos, o que é inquestionável ante o próprio texto da Constituição da República, cujo artigo $5^{\circ}$, inciso XLVII, admite a pena de morte em caso de guerra declarada na forma do artigo 84, inciso XIX. Corrobora esse entendimento o fato de o Código Penal prever, como causa excludente de ilicitude ou antijuridicidade, o aborto ético ou humanitário - quando o feto, mesmo sadio, seja resultado de estupro. Ao sopesar o direito à vida do feto e os direitos da mulher violentada, o legislador houve por bem priorizar estes em detrimento daquele - e, até aqui, ninguém ousou colocar em dúvida a constitucionalidade da previsão.” E afirmou a Ministra Cármen Lúcia, em seu voto na ADPF 54: "Em outras palavras, segundo nosso ordenamento jurídico o direito à vida e a tutela do direito à vida são dois aspectos de um mesmo direito, o qual, como todo direito fundamental, não é absoluto nem hierarquicamente superior a qualquer outro direito fundamental." (BRASIL, 2010, 2012).
} 


\section{Titularidade do Direito Fundamental à Vida no sistema constitucional brasileiro}

Já foi referido que a titularidade do direito fundamental à vida não é definida a partir de critérios científicos. Trata-se de categoria jurídica fixada à luz dos procedimentos democráticos e da interpretação dos enunciados normativos em vigor. Atualmente, é assentado no sistema jurídico brasileiro que todos os seres humanos que nascem vivos titularizam o direito fundamental à vida. Tal conclusão advém de enunciados normativos constitucionais (art. $5^{\circ}$, caput, c/c art. 12) combinados com os arts. $1^{\circ}$ e $2^{\circ}$ do Código Civil Brasileiro. ${ }^{32}$ Portanto, a partir da configuração do nascimento de um ser humano com vida, há titularidade do direito fundamental à vida, proposição que parece receber parcas contestações.

Apesar dessa zona de certeza - todos os seres que sobrevivem ao parto de mulher titularizam o direito fundamental à vida - há três grupos de entes que estão a protagonizar debates acerca da titularidade do direito, os animais não humanos, os embrióes externos ao útero e os embriões e fetos no útero. O último grupo recebe uma categorização exclusivamente jurídica no Brasil, são considerados nascituros. Principalmente ao ensejo de decisões recentes do Supremo Tribunal Federal, far-se-á uma descrição, acompanhada de breves reflexões, sobre cada uma das categorias e seu atual status jurídico.

No primeiro grupo, tem-se os animais não humanos. Tradicionalmente, os ordenamentos jurídicos calçados nos direitos fundamentais apoiam-se em um viés antropocêntrico. Posto que alguns sistemas constitucionais, como é o brasileiro, reconheçam proteção jurídica aos animais não humanos, não é habitual assumirem que há animais não humanos titulares de direitos fundamentais. No momento, essa é a regra. Muitos animais não humanos são considerados destinatários de proteção jurídica, sem que sejam titulares do direito fundamental à vida.

$\mathrm{Na}$ matéria, são marcantes alguns julgados do STF, nos quais se discutiu a crueldade com animais não humanos em alegadas práticas culturais, esportivas ou religiosas, como a farra do boi e as rinhas de galo. ${ }^{33}$ Nas duas situações, o Supremo Tribunal Federal não reconheceu o caráter religioso, tradicional e cultural ou esportivo das atividades, entendendo-as inadmissíveis diante da proibição constitucional da crueldade com os animais não humanos. Além disso, o STF sustentou a legislação infraconstitucional que protege os animais. Embora a titularidade de direitos não tenha sido ventilada - dirá sustentada -, o STF consagrou a proteção jurídica aos

\footnotetext{
32 Há outros enunciados normativos que corroboram essa interpretação, a exemplo do Estatuto da Criança e do Adolescente (ECA), cuja definição de criança está entrelaçada à de pessoa: "Art. $2^{\circ}$ - Considera-se criança, para os efeitos desta Lei, a pessoa até doze anos de idade incompletos, e adolescente aquela entre doze e dezoito anos de idade." Conforme o Código Civil Brasileiro, a personalidade inicia-se com o nascimento com vida: "Art. $2^{\circ}$ - A personalidade civil da pessoa começa do nascimento com vida; mas a lei põe a salvo, desde a concepção, os direitos do nascituro." (BRASIL, 2002, 1990). Os tipos penais também auxiliam, uma vez que traçam diferença entre homicídio e aborto.

33 Sobre a farra do boi, ver Brasil (1997). Sobre as rinhas de galo e similares, Brasil (2011, 2007, 2005).
} 
animais não humanos em relação a práticas consideradas cruéis. Na decisão mais recente, de 2011, o Tribunal asseverou, na ementa do julgado, inclusive, que a Constituição brasileira protege todas as formas de vida, não apenas a do gênero humano (BRASIL, 2011).

Está em aberto, ainda, o deslinde de uma Ação Direta de Inconstitucionalidade de lei estadual que permitiu o sacrifício ritual de animais não humanos domesticáveis em cultos de religiões de matriz afro-brasileira (BRASIL, 2012). ${ }^{34}$ Não há como predizer o resultado, é um caso difícil e guarda dessemelhanças em relação às rinhas de galo e à farra do boi, mas, à luz da integridade, soa distante do real esperar que o Tribunal conceda espaço para teorias que pugnam pelo reconhecimento da titularidade de direitos, ainda que de modo fraco, aos animais não humanos. ${ }^{35}$

No segundo e no terceiro grupos estão as questões mais intrincadas sobre a titularidade do direito fundamental à vida. Qual o status jurídico a conferir aos períodos iniciais da vida humana, aos embriões externos ao útero e aos embriões e fetos no útero? Nos últimos anos, o STF proferiu duas decisões emblemáticas sobre o assunto. A primeira lidou com os embriões extranumerários criopreservados e o seu uso em pesquisas científicas, como permitido pela lei de Biossegurança (BRASIL, 2010). A segunda, com a possibilidade de interrupção da gestação de feto portador de anencefalia (BRASIL, 2012).

$\mathrm{Na}$ ADI 3510, apesar de não ser possível desnudar a metodologia e as razões de decidir prevalentes, ${ }^{36}$ consegue-se identificar com clareza alguns pontos de acordo sobre o status jurídico dos embriões fora do útero. Em primeiro lugar, o objeto discutido foi adequadamente delimitado. Estava em pauta tão somente o status jurídico dos embriões extranumerários criopreservados. Não se tratava de uma discussão que abrangesse também a figura do nascituro e qualquer caso de aborto, pois a maioria da Corte separou três realidades: o embrião fora do útero, o nascituro (embrião ou feto no útero) e a pessoa, recusando o caráter de pessoa e, portanto, de titular de direitos aos dois primeiros.

Em segundo lugar, é nítido que os Ministros não decidiram sobre quando começa a vida humana. Decidiram, mediante filtros jurídicos, quando e em que medida

\footnotetext{
34 No tema: Rio Grande do Sul (2009, 2004) e Oro (2006).

35 Em outra oportunidade, escrevi: "O nascimento das teorias reconhecendo direitos fundamentais e as primeiras positivações desses direitos foram marcados por um viés altamente antropocentrista. O mesmo pode ser dito sobre as declarações internacionais de direitos humanos. Com o tempo, novos direitos foram agregados, alguns deles referentes ao meio-ambiente, englobando a fauna e a flora. De início, a sua proteção continuava ligada ao ser humano, ainda em um olhar antropocêntrico. Recentemente, os estudiosos passaram também a laborar em um viés biocentrista, no qual a tutela destinada aos seres vivos é importante por si, pois se admite que os seres vivos, especialmente os animais não humanos, devem ser destinatários de salvaguarda jurídica por seus próprios interesses e não apenas em razão dos interesses humanos. $\mathrm{A} \mathrm{CF} / 88$ possui um Capítulo sobre o meio-ambiente, redigido em clara conotação antropocêntrica, no qual proíbe a submissão de animais à crueldade." Sobre o tema, ver Singer (2002), Feinberg (1980, p. 159-206), Regan (2004) e Nussbaum e Sunstein (2004).

36 A decisão conta com mais de 600 páginas e os Ministros empregaram não apenas argumentos distintos entre si, ligados a diferentes correntes de filosofia constitucional, como também metodologias dissonantes. Nesse ângulo, é uma decisão criticável, pois dela não emana nem um roteiro de argumentação, nem de metodologia decisória para casos análogos. Todavia, quanto a alguns efeitos da decisão, é possível extrair conclusões um tanto mais firmes.
} 
o ordenamento jurídico protege determinados entes e a partir de qual momento reconhece a titularidade de direitos. Partindo das três realidades jurídicas - embriões, nascituro e pessoa - e seguindo o método da integridade dworkiniano, o Ministro Relator concluiu que o ordenamento jurídico brasileiro perfilha a teoria natalista, ou seja, é o nascimento com vida o marco para a titularidade de direitos. Antes disso, tanto o embrião fora do útero quanto o nascituro são destinatários de proteção. Interessa anotar que a conclusão de ser a teoria natalista a adotada no sistema brasileiro figura expressamente na Ementa do julgado, indicando que a maioria do Supremo Tribunal Federal assentou o posicionamento, buscando dirimir desacordos jurisprudenciais e doutrinários. Nisso, a decisão assumiu certa tonalidade maximalista, ao extrapolar a figura do embriáo fora do útero, para o qual bastaria a exclusão da teoria concepcionista (BRASIL, 2010). ${ }^{37}$

À primeira vista, oferecer proteção jurídica e recusar a titularidade de direitos parece muito pouco, pois conduziria a um posicionamento binário extremado: ou se é pessoa, ou se é coisa. Em sendo coisa, estaria o ente desamparado de tutela jurídica e de cuidados especiais. A esteira de raciocínio não é uma decorrência necessária. A um ente não considerado pessoa pode ser reputado um bem que merece - por interesses próprios ou alheios - ser destinatário de intensa proteção jurídica. As modalidades de cautela e de proteção discutidas no STF, como consequência de ter o Ministro Gilmar Mendes lançado proposta de uma decisão aditiva, demonstram isso. Os Ministros debateram os arranjos institucionais e os níveis de proteção conferidos aos embriões humanos criopreservados. Apesar de a proposta não ter sido aceita, nota-se que várias condições e regras para a produção, a circulação, o armazenamento, a manipulação e o descarte de embriões humanos existentes foram inventariadas e consideradas suficientes. Assim, claro é que, no sistema brasileiro, os embriões humanos extranumerários criopreservados não foram tomados por um objeto qualquer. Estão absolutamente fora do comércio, não podem ser produzidos em desvinculação ao emprego das técnicas de reprodução humana assistida, não podem ser usados em pesquisas sem o consentimento dos doadores do material; as pesquisas devem seguir as regras estritas existentes, sobre supervisão do sistema CEP-CONEP, entre outras cautelas (BRASIL, 2010). ${ }^{38}$ Ser destinatário de proteção, portanto, é muito significativo e, em certas circunstâncias, é elemento que justifica a restrição de direitos alheios.

Em terceiro lugar, a maioria do STF, nas palavras do Ministro Relator, afirmou que a Constituição Federal silencia sobre o momento em que a vida humana adquire proteção jurídica e sobre o momento em que reconhece a titularidade de direitos. Segundo o Ministro, esse "mutismo constitucional" é "hermeneuticamente significante" (BRASIL, 2010), ${ }^{39}$ ou seja, o constituinte recusou-se a inserir no texto a concepção como a divisa para a aquisição de personalidade jurídica e deixou

\footnotetext{
37 Sobre os conceitos de minimalismo e de maximalismo, ver Sunstein (1999). Em vernáculo: Oliveira (2007).

38 Especialmente o voto do Ministro Gilmar Mendes.

39 Voto do Ministro Relator.
} 
desobstruído o caminho para a definição pelos poderes constituídos, em especial o legislador democraticamente eleito e responsivo. Com isso, respeitada foi a escolha legislativa, aposta na lei de Biossegurança, de não ser o embrião humano extranumerário criopreservado pessoa, bem como de poder ser utilizado em determinadas pesquisas científicas. Caso as forças democráticas venham a pender para outro sentido, o silêncio constitucional sinalizaria a necessidade de deferência por parte do Supremo Tribunal Federal.

No que toca à titularidade do direito fundamental à vida pelo nascituro, a decisão proferida na ADI 3510 assinalou adesão à teoria natalista, isto é, a proteção à figura do nascituro, sem implicar na titularidade de direitos. Porém, os debates travados na $\mathrm{ADPF} 54$ propagaram algumas dúvidas no tema..$^{40} \mathrm{O}$ núcleo argumentativo da maioria do Supremo Tribunal Federal ancorou-se na não titularidade do direito fundamental à vida pelo feto com diagnóstico de anencefalia, uma vez que ele seria um natimorto cerebral..$^{41}$ Portanto, a antecipação do parto constituiria um fato atípico, pela ausência de viabilidade de vida extrauterina.

Essa linha argumentativa pode dar vazão à ideia de que o feto titularizaria o direito fundamental à vida, se viável. A contribuir, o modo de decidir do Ministro Marco Aurélio, Relator. Ao considerar o feto portador de anencefalia inviável para a vida extrauterina e, portanto, um natimorto, ele afirma que há apenas um conflito aparente de direitos. Se fosse viável, haveria conflito. Aqui, percebe-se alguma desarmonia em relação à teoria natalista, tal qual estabelecida na ADI 3510. Pode haver, portanto, confusão. Na melhor leitura possível, unindo as razões de decidir da ADI 3510 e da ADPF 54, ter-se-ia que o nascituro viável para a vida extrauterina recebe um maior grau de proteção do que o nascituro inviável, justamente em razão da potencialidade do primeiro de adquirir personalidade jurídica e de titularizar o direito à vida. ${ }^{42}$

\footnotetext{
${ }^{40}$ Em alguns votos, a despeito do decidido na ADI 3510, pode-se ler que o nascituro ou feto no útero titulariza direitos, o que traz confusão e ausência de linearidade decisória a um tema tão sensível. Como exemplo, trecho do voto da Ministra Rosa Weber: "Todavia, é fato que há interesse na proteção do feto, pois a lei reconhece que tem direitos." A redação formulada por Rosa Weber introduz dúvidas sobre um ponto que a maioria do STF, especialmente o Ministro Relator, tentara sedimentar na ADI 3510, a diferença entre ser destinatário de proteção pelo ordenamento jurídico e ser titular de direitos. Nesse voto, a Ministra Rosa Weber demonstra que a vida humana, para o direito penal, possui diferentes gradações de proteção. Ao comentar o âmbito do direito civil, a Ministra tende à teoria da personalidade condicional, que fora expressamente recusada na ADI 3510. Embora este trecho do voto de Rosa Weber seja um dictum, diversamente da adoção da teoria natalista na ADI 3510 - parte da ratio decidendi - ele pode reacender o debate em torno da titularidade de direitos pelo nascituro. Seria importante, em assunto tão recheado de controvérsias, maior adesão ao precedente, bem como muita cautela no uso dos conceitos (BRASIL, 2012).

${ }_{41}$ No voto do Ministro Relator lê-se: "Anencefalia e vida são termos antitéticos. Conforme demonstrado, o feto anencéfalo não tem potencialidade de vida. Trata-se, na expressão adotada pelo Conselho Federal de Medicina e por abalizados especialistas, de um natimorto cerebral. Por ser absolutamente inviável, o anencéfalo não tem a expectativa nem é ou será titular do direito à vida, motivo pelo qual aludi, no início do voto, a um conflito apenas aparente entre direitos fundamentais. Em rigor, no outro lado da balança, em contraposição aos direitos da mulher, não se encontra o direito à vida ou à dignidade humana de quem está por vir, justamente porque não há ninguém por vir, não há viabilidade de vida." (BRASIL. 2012, p. 60).

42 Pertinente lembrar que o Ministro Marco Aurélio mencionou que entende que o feto não titulariza direitos, mas elaborou o argumento como se o feto titular fosse, para demonstrar que atingiria o mesmo resultado final.
} 
Nesse aspecto, o Ministro Gilmar Mendes chamou a atenção para um problema interpretativo que a linha da maioria do STF poderia causar. Ao considerar que o feto portador de anencefalia é um natimorto e optar pela atipicidade da conduta, a maioria determinou que um feto portador de anencefalia não nascerá com vida, será, necessariamente, um natimorto. Para chegar à conclusão, os Ministros Marco Aurélio, Rosa Weber e Cármen Lúcia formularam o seguinte raciocínio: (a) a qualidade de vida e (b) o critério de morte atualmente em vigor no sistema jurídico brasileiro. Para eles, um bebê com anencefalia atenderia aos critérios de morte encefálica e não apresentaria as qualidades que devem estar presentes na vida humana hábil a titularizar direitos, quais sejam,

[...] os fenômenos da vida psíquica, mas também a sensibilidade, a mobilidade, a integração de quase todas as funções corpóreas. O feto anencefálico não desfruta de nenhuma função superior do sistema nervoso central 'responsável pela consciência, cognição, vida relacional, comunicação, afetividade e emotividade'. ${ }^{3}$

Ao traçar as características necessárias para que a vida humana seja suficientemente qualificada para a titularidade do direito fundamental à vida, os $\mathrm{Mi}$ nistros estariam saindo do cenário do simples nascimento com vida (aferido por autonomia respiratória) e adentrando na determinação e averiguação de alguns elementos que tornam a vida humana juridicamente relevante a ponto de ensejar quer o interesse de proteção, quer a titularidade do direito fundamental à vida. Estariam optando pelo modelo qualidade de vida, para o qual o valor de uma vida humana é contingente e responde às circunstâncias, usualmente mensuráveis segundo alguns parâmetros considerados relevantes (ilustrativamente, proximidade da morte, presença de dor e sofrimento, impossibilidade de vida independente de aparelhos ou do organismo alheio - materno inclusive -, nível de relacionamento com o ambiente externo e com outros seres humanos e consciência). Nota-se que há um giro no argumento, tanto em virtude da teoria natalista anteriormente escolhida quanto em virtude de outras situações de vida humana extremamente adversas. ${ }^{44}$

Perceba-se que um nascituro viável potencialmente apresentará as qualidades enumeradas, ao passo que um portador de anencefalia jamais as ostentará. A diferença justificaria, então, reservar proteção jurídica maior aos primeiros. Todavia, se não for muito bem demarcado, o modelo da qualidade de vida pode produzir efeitos colaterais de monta. Por exemplo, uma pessoa, ser humano adulto em estado vegetativo persistente, não apresenta as qualidades enumeradas pelos Ministros, pois não se comunica, não se relaciona, não demonstra afetividade nem emotivida-

\footnotetext{
${ }_{43}$ Trecho do voto do Min. Marco Aurélio, inspirado nas palavras de um dos profissionais ouvidos na Audiência Pública. As mesmas qualidades são elencadas nos votos das Ministras Rosa Weber, que lidou com a perspectiva intitulada qualidade de vida, e Carmen Lúcia, que denominou Vida digna (BRASIL, 2012, p. 13, 20).

44 Sobre os modelos de santidade da vida e de qualidade de vida, ver Singer (1983, p. 128). É de interesse consultar a revisão e as indagações lançadas por Schramm (2009, p. 377-389).
} 
de, não ostenta habilidades cognitivas e é muito duvidoso que detenha consciência. Em trilha paralela, bebês que nascem com outras síndromes e deficiências muito severas também não atendem às qualidades seletas. Para evitar essas aberturas, os Ministros referidos anunciaram componentes do modelo da qualidade de vida, mas construíram um obstáculo ao unir os qualificadores ao atual critério de morte empregado no direito brasileiro, o da morte encefálica.

Ainda que tenham circunscrito com precisão - especialmente na parte inicial do voto da Ministra Rosa Weber - os campos normativos das ciências da saúde e do direito, os Ministros recorreram ao critério de morte encefálica e o aplicaram para asseverar que os fetos portadores de anencefalia não detêm potencialidade de apresentar os qualificadores de uma vida relevante juridicamente $e$ não atingirão, ao nascer, o critério de vida obtido pelo marcador de seu oposto, a morte encefálica. É preciso, então, aliar os dois elementos. E a maioria considerou que um bebê nascido com anencefalia não preenche nenhum dos critérios.

É exatamente aí que está a perspicaz crítica elaborada pelo Ministro Gilmar Mendes. Excluir a tipicidade por considerar que o critério de morte encefálica será invariavelmente atingido por um bebê nascido com anencefalia, ou seja, porque haverá sempre um natimorto, constrói uma estranha relação entre o critério de verificação clínico da morte e o nível de proteção jurídica destinado àquele que nasce. ${ }^{45} \mathrm{O}$ nascimento com vida ainda é aferido pela respiração autônoma e o critério de morte encefálica não é aplicável, segundo os ditames da ciência, antes do sétimo dia de vida de um bebê. ${ }^{46}$ É por essa razão que o Ministro frisou que o melhor seria a exclusão da ilicitude da conduta, não da sua atipicidade. Assim, se um bebê nascido com anencefalia respirar autonomamente, o fato não alterará o desfecho e as consequências jurídicas do problema da antecipação do parto, tampouco haverá determinação apriorística, pelos operadores do direito, de quais seres humanos nascem com vida à luz do critério científico da morte encefálica.

Diante da discussão existente sobre se os bebês portadores de anencefalia atingem ou não - mesmo que por tempo muito limitado - os níveis mínimos de atividade encefálica, mais adequado seria que o direito não estabelecesse que os critérios de morte encefálica serão sempre atingidos (i.e, $100 \%$ dos casos), mormente ao se considerar que o critério de morte encefálica apenas pode ser aplicado após o sétimo dia do nascimento, o que reforça a noção de que o nascimento com vida tem

\footnotetext{
45 Gilmar Mendes lembra que, em casos de gestação decorrente de violência sexual e de risco de vida à gestante, a viabilidade do nascituro não é posta em dúvida. Por isso, uma decisão jurídica poderia contornar o debate científico sobre a anencefalia, assim como evitar as veredas dos argumentos do modelo da qualidade de vida (BRASIL, 2012). 46 Essa afirmação não contradiz nem critica a distinção entre os campos normativos do direito e das ciências da saúde. Mas rebate um ponto que considera equívoco no modo como a relação foi posta em movimento pela Ministra Rosa Weber. Uma das poucas vias que não pode ser tomada é oferecer destinação impossível aos métodos e conhecimentos científicos, ou seja, determinar juridicamente eficácias, possibilidade de utilização, níveis de segurança, etc. É a medicina baseada em evidência que estabelece que o critério de morte encefálica não é aplicável antes do sétimo dia de vida. Assim, como o direito afirmará que houve morte encefálica? O que haveria, em sentido jurídico, é a admissão de que, vivo ou não vivo ao nascer, os níveis de proteção destinados ao feto portador de anencefalia não se sobrepõem aos direitos da gestante.
} 
como marca a respiração autônoma, não os níveis de atividade encefálica. Talvez a formulação da maioria, principalmente se considerada a construção argumentativa da Ministra Rosa Weber, tenha alterado o medidor do nascimento com vida.

O olhar do Ministro Gilmar Mendes foi acurado. Há reflexos jurídicos importantes entre um e outro sulco argumentativo, apesar de o efeito principal ser o mesmo. O primeiro reflexo está na proteção da decisão da gestante de um feto portador de anencefalia. Se o STF considerou que tal feto será um natimorto, fragiliza-se a proteção dos estágios de vida intrauterina e até mesmo o atendimento pleno à gestante que decide não antecipar o parto. O segundo reflexo está no status jurídico do nascido. Se, por ventura, o bebê respirar autonomamente por algum período - por hipótese - duas horas - estarão os profissionais da saúde dispensados de qualquer investimento? Têm os pais habilidade decisória sobre o investimento clínico? Terá o bebê direito ao nome, ao atestado de óbito, a contar na linha sucessória, a ser amparado pelo plano de saúde pago pelos genitores? Se natimorto, não titularizará direitos e, uma vez fora do útero, não terá direitos próprios, nem terá qualquer proteção mais ampla do que a recebida pelos cadáveres? O modo de estruturar os argumentos selecionado pelo Ministro Gilmar Mendes tem as virtudes de manter mais acuradas as distinções entre campos normativos das ciências da saúde e do direito, de evitar as discussões mencionadas - mostrando-se mais protetivo do direito de escolha da gestante e menos peremptório acerca do status jurídico do neonato -, bem como de potencializar menores indagações sobre o modelo da qualidade de vida.

Do exposto, percebe-se que o modo de argumentar seguido pela maioria do STF na ADPF 54 traz muitos elementos ao debate, carrega em si algumas imprecisões e obscuridades, além de ocasionar certo desalinho quanto aos critérios a serem aplicados para a aferição do nascimento com vida e da ocorrência da morte em neonatos. Entrementes, a maioria deixou assentado que:

a) incumbe à gestante, como direito feminino, decidir pela continuidade da gestação ou pela antecipação terapêutica do parto, quando houver diagnóstico de anencefalia;

b) a antecipação terapêutica do parto de feto diagnosticado com anencefalia é fato atípico;

c) se houver nascimento de um bebê com anencefalia, será um natimorto, portanto, não titularizará o direito fundamental à vida;

d) o feto com diagnóstico de anencefalia não titulariza o direito fundamental à vida.

Em conclusão, tem-se que na atual fase do direito brasileiro, os animais não humanos, os embriões fora do útero e os nascituros não titularizam o direito fundamental à vida, sendo destinatários de diferentes graus de proteção jurídica. O feto com diagnóstico de anencefalia é também destinatário de proteção, porém, em um grau menor do que os demais fetos. Além disso, uma vez nascido, um bebê portador 
de anencefalia não titularizará o direito fundamental à vida, pois será juridicamente um natimorto.

\section{Questões polêmicas sobre a terminalidade da vida humana e o sistema constitucional brasileiro}

A titularidade do direito fundamental à vida cessa com a morte. Se existem discussões sobre a titularidade do direito à vida nas fases iniciais do processo de viver humano, elas não se transportam com a mesma intensidade para o espectro do final da vida. Uma vez nascido vivo, há titularidade do direito, elemento que não se perde pela baixa qualidade de vida, nem pelo enfrentamento de circunstâncias extremas, tampouco em função de comportamentos ativos ou omissivos do titular.

Atualmente, vigora no sistema jurídico um critério para fixar a ocorrência do evento morte, a morte encefálica. A adoção desse marcador ocorreu na Lei de Transplantes, existindo expressa delegação para que o Conselho Federal de Medicina estabeleça os protocolos clínicos e tecnológicos de aferição. ${ }^{47} \mathrm{~A}$ escolha do critério da morte encefálica não significa a relação direta entre as ciências da saúde e o direito. Significa, apenas, qual é o elemento juridicamente determinante. ${ }^{48,49}$

A opção clara por um definidor jurídico é demasiado importante, pois toda a estruturação conceitual relativa ao final da vida humana depende do conceito de morte e do critério adotado para caracterizar o evento. Assim, não há que se falar em eutanásia ou em ortotanásia de um paciente com morte encefálica diagnosticada, ainda que suas atividades cardiorrespiratórias sejam mantidas. Interessa, então, perguntar: qual é o tratamento jurídico hoje proporcionado pelo sistema jurídico brasileiro à morte com intervenção? Quais são os comportamentos permitidos, quais os proibidos e em quais circunstâncias?

As práticas da eutanásia e do suicídio assistido são proibidas no Brasil. ${ }^{50}$ Já a ortotanásia é permitida. A admissão explícita aconteceu no final de 2006, mediante

\footnotetext{
${ }_{47}$ Assim dispõe o art. $3^{\circ}$ da Lei Transplantes: "Art. $3^{\circ}$ - A retirada post mortem de tecidos, órgãos ou partes do corpo humano destinados a transplante ou tratamento deverá ser precedida de diagnóstico de morte encefálica, constatada e registrada por dois médicos não participantes das equipes de remoção e transplante, mediante a utilização de critérios clínicos e tecnológicos definidos por resolução do Conselho Federal de Medicina." Logo após a aprovação do texto legal, o CFM editou a Resolução n.1.480/1997, na qual delineou os procedimentos para diagnóstico de morte encefálica. No assunto, ver também a Resolução n. 1827/2007, que disciplina a utilização do mesmo critério para pacientes não doadores de órgãos (BRASIL, 1997b, 1997a, 2007).

48 O critério-padrão é fruto do Informe Harvard, documento de bases utilitaristas publicado no Journal of American Medical Association em agosto de 1968 (BEECHER, 1968, p. 85-88). Para uma explanação e discussão, ver Gherardi (2006, p. 102-121).

49 Evidentemente, o critério-padrão pode ser alterado. Já são discutidos outros mecanismos para a aferição da morte de um ser humano. Estão fora das pretensões deste estudo as novas propostas e suas consequências. Demais disso, é preciso ter em mente que o critério da morte encefálica é a barreira última. Haverá muitos casos em que sequer será necessário a ele recorrer, podendo ser atestada a morte por outros balizadores que, necessariamente, são mais amplos e englobam a ocorrência de morte encefálica.

50 Sobre a eutanásia: "Compreende-se que a eutanásia é a ação médica intencional de provocar a morte - com exclusiva finalidade benevolente - de pessoa que se encontre em situação considerada irreversível e incurável, consoante os padrões médico-científicos vigentes, e que padeça de intensos sofrimentos físicos e psíquicos. Do conceito estão excluídas a assim chamada eutanásia passiva, ocasionada por omissão, bem como a indireta, ocasionada por
} 
Resolução do Conselho Federal de Medicina. Consoante os enunciados normativos da Resolução, é permitido aos profissionais da medicina limitar ou suspender procedimentos e tratamentos hábeis a prolongar a vida do paciente em fase terminal, acometido de doença grave e incurável, desde que exista consentimento livre e esclarecido do paciente ou de seu representante legal. A legalidade e a constitucionalidade da Resolução foram questionadas em Ação Civil Pública, a conhecida ACP da Ortotanásia, tanto em razão de aspectos formais quanto de materiais. A decisão final reconheceu plena validade à Resolução do Conselho Federal de Medicina (BRASIL, 2014). ${ }^{51}$

Assim, é lícita a prática da ortotanásia, desde que presentes os seguintes requisitos: (a) terminalidade; (b) doença grave e incurável; e (c) consentimento livre e esclarecido do paciente ou de seu responsável legal, se incapaz o paciente. Seguindo as diretrizes, é preciso que exista terminalidade, não sendo suficiente apenas a presença de doença grave e incurável.

Pese embora a permissão da ortotanásia, o cenário é arenoso. Por um lado, os contornos das ideias de terminalidade e de ortotanásia são elásticos. Por outro lado, há agora uma hipótese de disposição de posições subjetivas do direito fundamental à vida, bem como uma nova hipótese de interferência heterônoma com posições subjetivas do direito fundamental à vida, as duas em rumo diverso ao que era tradicionalmente admitido.

Para efeitos deste estudo, importa deter a atenção no segundo ponto, a disposição de posições subjetivas do direito fundamental à vida e as situações de interferência heterônoma legítima. Sabe-se que a ortotanásia se caracteriza eminentemente por comportamentos omissivos desprovidos da intenção direta de causar a morte do paciente..$^{52}$ Exatamente quais condutas omissivas estão englobadas pelo conceito é matéria recheada de dúvidas, mas há inclinação em admitir que envolva os cuidados paliativos, a retirada e a não oferta de suporte vital, ${ }^{53}$ a não ressuscitação e a não reanimação quando houver parada cardiorrespiratória, a não realização de cirurgias e a não administração de alguns tratamentos para doenças subjacentes..$^{54}$

\footnotetext{
ação desprovida da intenção de provocar a morte. Não se confunde, também, com o homicídio piedoso, conceito mais amplo que contém o de eutanásia." Sobre o suicídio assistido: "Por suicídio assistido, entende-se a retirada da própria vida com auxílio ou assistência de terceiro. $\mathrm{O}$ ato causador da morte é de autoria daquele que põe termo à própria vida. O terceiro colabora com o ato, quer prestando informações, quer disponibilizando os meios e condições necessárias à prática. O auxílio e a assistência diferem do induzimento e da instigação ao suicídio. No primeiro, a iniciativa advém do sujeito passivo; no outro, terceiro atua sobre as habilidades da agência do sujeito passivo, de modo a obnubilar sua liberdade de ação. As duas formas admitem combinação, isto é, há possibilidade de uma pessoa ser simultaneamente instigada e assistida em seu suicídio. O suicídio assistido por médico é espécie do gênero suicídio assistido." (MARTEL, 2010).

${ }^{51}$ Os demais documentos foram obtidos via correspondência eletrônica. Agradeço a Daniel Sarmento por disponibilizá-los.

${ }^{52}$ Existem sérias discussões sobre a distinção entre comportamentos omissivos e comportamentos comissivos na morte com intervenção. No tema, Lopes Junior (2014).

${ }^{53}$ Quanto à retirada ou não oferta do suporte vital, é bem mais controversa a questão da não oferta ou suspensão de mecanismos de alimentação do que de respiração. Então, mesmo que pareça haver consenso, os limites de cada comportamento são disputados.

${ }^{54}$ O não tratamento de enfermidades, por exemplo, de uma pneumonia em paciente com câncer esofágico em estágio terminal, é também objeto de contendas.
} 
Outrossim, se o paciente terminal e acometido de doença grave e incurável consentir na omissão de atos médicos que prolongariam a sua vida, estará abrindo mão das posições subjetivas derivadas da interpretação positiva do seu direito fundamental à vida (as posições $\mathrm{DV}(\mathrm{c})$ e $\mathrm{DV}(\mathrm{d})$ supracitadas). Com isso, modifica-se a reiterada compreensão de que as posições subjetivas do direito fundamental à vida são indisponíveis, ou seja, de que o consentimento do titular não é hábil a permitir que terceiros se comportem de modo que seria proibido se não houvesse o consentimento. O consentimento do titular permite ou até obriga o terceiro a comportar-se de determinada maneira, modificando as relações formadas pelas posições jurídicas subjetivas do direito. Ao permitir que terceiros ajam de forma que não deveriam se não houvesse o consentimento, o titular dispõe de posições subjetivas do direito fundamental à vida, sem deixar de titularizá-las. Segue titular e pode, a qualquer momento, retirar seu consentimento e retratar-se.

Por exemplo, se um paciente consente com uma ordem de não ressuscitação e, depois de alguns dias, muda de ideia, estará livre para fazê-lo. Mais importante, segue titular porque continua em plenitude com as duas primeiras posições subjetivas do direito fundamental à vida (DV(a) e DV(b) supracitadas). Então, se um paciente $\mathrm{X}$ for morto a tiros por um assaltante, ainda que esteja em cuidados paliativos e tenha consentido com ordens de não reanimação, haverá um crime de homicídio. No mesmo ensejo, se outro paciente retirar o suporte vital ou suspender a medicação do paciente $\mathrm{X}$, violará as posições subjetivas do direito à vida de $\mathrm{X}$. A chave da disposição está no consentimento genuíno e encampa, também, a definição exata de quem são os terceiros a quem se permite os comportamentos que seriam proibidos.

Nitidamente, o consentimento do titular que altera as posições subjetivas do direito fundamental à vida há de ser marcado pela genuinidade, pois é uma manifestação da liberdade do sujeito que, desde um ponto de vista interno, valora sua própria existência e toma decisões. ${ }^{55} \mathrm{O}$ dimensionamento entre a sacralidade de vida e a qualidade de vida ocorre pelo próprio titular do direto. Assaz diversa é a avaliação heterônoma, externa ao sujeito. Por isso, em forte linha de princípio, deve ser do titular a escolha e ela deve ser vinculante para a equipe de saúde e familiares.

Todavia, haverá situações nas quais o indivíduo acometido por doença grave e incurável, em estágio terminal e intenso sofrimento, não será capaz de decidir por si. O feixe é amplo, envolvendo desde neonatos, crianças, pessoas com transtornos mentais severos, bem como a própria inabilidade para decidir ou manifestar decisões advindas do estado de saúde (e.g., torpor medicamentoso, coma, ausência de habilidade para comunicar-se, estado psicótico). Nesses casos, existe permissão para que os responsáveis legais decidam em nome do paciente. A decisão não configura disposição de posições subjetivas do direito fundamental à vida, mas interferência heterônoma com as posições $\mathrm{DV}(\mathrm{c})$ e $\mathrm{DV}(\mathrm{d})$ em face da equipe de saúde. Aqui, o

55 Sobre o consentimento, imprescindível consultar Beyleveld e Brownsword (2007). Ver, também, Martel (2010). 
equacionamento da qualidade de vida será feita pelos responsáveis legais ou convencionais, não pelo titular do direito. ${ }^{56}$

Existem muitos pontos a serem pensados quanto à decisão pelos responsáveis legais. A Resolução do Conselho Federal de Medicina é lacunosa e não oferece guias suficientes, tornando-se menos segura quando interpretada ao ensejo das normas civilistas sobre representação e decisão por terceiros. Ilustrativamente, podem ser mencionados alguns problemas jurídicos a merecerem desenvolvimento e regulamentação:

a) os critérios para aferição da habilidade decisória demandam fina sintonia, pois, se penderem para extremos, podem levar à aceitação tanto de consentimentos muito duvidosos quanto de retirada de autonomia de sujeitos capazes, mas que tomam decisões que desagradam seus familiares ou equipes de saúde;

b) a definição de uma linha de representantes;

c) o trato da representação para uma pessoa que, a rigor técnico-jurídico, ainda pode ser capaz civilmente, mas inabilitada pelas circunstâncias para tomar decisões;

d) a presença de conflitos de interesses;

e) o modo de decidir que deve ser adotado pelos representantes e pelos demais envolvidos em casos de conflito (equipes de saúde, comitês de bioética clínica, papel do Ministério Público e do Poder Judiciário, mecanismos de interlocução, etc.).

No assunto, há carência de guias mais seguras de boas práticas, aceitáveis e, dentro do necessário, convergentes, tanto para a assistência em saúde, quanto para o sistema jurídico. ${ }^{57}$

Cerca de dois anos depois da confirmação jurisdicional da validade da normativa sobre a ortotanásia, o CFM atuou novamente, introduzindo um instituto no direito brasileiro, as diretrizes antecipadas, vulgarmente conhecidas como testamentos vitais. ${ }^{58}$ Soaria natural crer que as bases das diretrizes antecipadas foram

\footnotetext{
${ }_{56}$ Em outro texto, abordei o assunto em pormenor, ver Martel (2010).

57 Em outra oportunidade, escrevi sobre o tema, apresentando alguns padrões que podem auxiliar na construção de processos decisórios, minimizar conflitos e dilemas, valorizar os direitos do paciente e a segurança da equipe de saúde, sempre à luz de proposições já consolidadas em alguns países, mormente aqueles que já tornaram lícitas as práticas há algum tempo (MARTEL, 2010; BARROSO; MARTEL, 2010, p. 27-62).

58 Quanto às diretrizes antecipadas, mantenho a mesma definição que apresentei em outra pesquisa, muito embora ela não esteja em plena conformidade aos enunciados da Resolução CFM n. 1.995/2012: "Por diretrizes antecipadas, compreende-se o documento jurídico pessoal, formal, em que um sujeito do consentimento expressa a quais tratamentos, intervenções médicas e situações pretende ou não ser submetido na assistência e, eventualmente, na pesquisa em saúde, para o caso de inconsciência ou de incapacidade futura. Isto é, enquanto sujeito do consentimento ele expressa seu consentimento, para a eventualidade de perder o status. Quando empregadas em situações cujo prognóstico é de irreversibilidade, usa-se intitulá-las testamento vital. As diretrizes antecipadas podem ser também o documento jurídico-formal no qual o sujeito do consentimento indica uma ou mais pessoas como responsáveis para tomar decisões acerca da assistência médica, para o caso de inconsciência ou incapacidade futura, ou seja, institui um representante
} 
traçadas visando a minimizar falhas da Resolução CFM n. 1.805/2006 e provavelmente com a intenção de valorizar o processo decisório e a liberdade do paciente - partindo da premissa de que as escolhas de final de vida feitas pelo próprio titular são as mais próximas do ideal, uma vez que reafirmam os direitos de liberdade e protegem o sujeito. Entretanto, o texto da Resolução CFM n. 1.995/2012 não traduz esse pensar, uma vez que peca tanto pela técnica de redação, quanto pelo potencial de decisão que lança nas mãos dos profissionais da medicina.

No momento, a Resolução é objeto de debate em Ação Civil Pública ajuizada pelo Ministério Público Federal, que contestou tanto aspectos formais - legitimidade e validade da atuação normativa do Conselho Federal de Medicina -, quanto aspectos materiais. ${ }^{59}$

Diante do texto da Resolução e de seu questionamento em Ação Civil Pública, é conveniente redigir algumas considerações, com enfoque para os itens defectivos e polêmicos. Em primeiro lugar, a técnica de redação dos enunciados normativos da Resolução CFM n. 1.995/2012 é bastante precária. Na exposição de motivos, existe claro enlace entre as diretrizes antecipadas e a terminalidade da vida. ${ }^{60}$ Porém, o elo não se encontra no texto normativo propriamente dito, o que enseja brechas interpretativas consideráveis. Suponha-se que uma pessoa saudável seja atropelada e esteja inconsciente. Para que possa viver, faz-se necessária amputação de uma das pernas. Porém, ao entrar na ambulância e ainda consciente, a pessoa informou que não desejava qualquer amputação e preferiria morrer. Não se trata de um caso de terminalidade ou de uma decisão de final de vida, mas houve recusa nos termos exigidos pela Resolução CFM n. 1.995/2012. A hipótese é muito distinta daquela de um paciente que, acometido de enfermidade incurável e, em processo irreversível

convencional, oferecendo-lhe linhas de atuação mais ou menos delimitadas, ou simplesmente deixando em suas mãos as decisões. Na definição estadunidense: "[...] advance directive. 1. a document that takes effect upon one's incompetence and designates a surrogate decision-maker for healthcare matters [...] 2. a legal document explaining one's wishes about medical treatment if one becomes incompetent or unable to communicate [...] 3. DO-NOT RESUSCITATE ORDER. Living will: An instrument, signed with the formalities of statutory required for a will, by which a person directs that his or her life not be artificially prolonged by extraordinary measures when there is no reasonable expectation of recovery from extreme physical or mental disability." (GARNER, 2004), vocábulos advance directive e living will. Conferir também: Buchanan (1988, p. 277-302) e Brock (2000, p. 154-155). O mais usual, no Brasil, é entender que "[...] os testamentos vitais são utilizados para dispor sobre a assistência médica a ser prestada ao paciente terminal, enquanto as diretivas antecipadas são usadas para dispor sobre tratamentos médicos em geral, dos quais o paciente pode se recuperar ou não. Há, portanto, inteira continência entre os dois institutos, não se justificando um esforço teórico para distingui-los. Temos unificado a terminologia para evitar dúvidas e assegurar a construção nominal do instituto em Língua Portuguesa, mantendo a cognação com o original em inglês: advance directives." (RIBEIRO, 2006). Discutindo o instituto do testamento vital para os casos de terminalidade e sua validade no Brasil, ver Teixeira e Penalva (2010, p. 57-82). Ver também a importante diferença acerca dos testamentos vitais (ato inter vivos) e do regime jurídico dos testamentos (mortis causa) no Brasil com Nevares (2010, p. 83-99).

59 Os principais argumentos são os seguintes: (a) questões formais: excesso em atividade normativa por órgão da Administração Pública, ensejando ilegalidade da medida; (b) questóes materiais: ameaça à segurança jurídica, alijamento da família do processo decisório e fragilidade da forma de registro das diretrizes (prontuário médico). Conforme Brasil (2013), o pedido de antecipação da tutela foi rejeitado.

${ }^{60}$ A Justificativa de número 1 dá o tom: "1) Dificuldade de comunicação do paciente em fim de vida.

Um aspecto relevante no contexto do final da vida do paciente, quando são adotadas decisões médicas cruciais a seu respeito, consiste na incapacidade de comunicação que afeta 95\% dos pacientes (D'AMICO et al., 2009). Nesse contexto, as decisões médicas sobre seu atendimento são adotadas com a participação de outras pessoas que podem desconhecer suas vontades e, em consequência, desrespeitá-las.” (D’AMICO et al., 2009 apud BRASIL, 2012). 
de morte, opta por não autorizar amputações sucessivas que prolongariam sua vida por um breve período. Diante dos enunciados normativos disponíveis, as situações podem confundir-se. As hipóteses fáticas de aplicação da Resolução não foram bem estipuladas, elemento imprescindível para a segurança de todos os envolvidos e para a manutenção do fio de integridade no sistema jurídico. ${ }^{61}$

Em segundo lugar, o texto da Resolução pode conduzir a ambiguidades que desaguam na assim chamada soberania médica. O núcleo das diretrizes antecipadas estaria na preservação da liberdade do indivíduo, para que suas escolhas e sua trajetória de vida sejam respeitadas no processo de morrer. Entrementes, a Resolução CFM n. 1.995/2012 determina que o profissional de medicina "levará em consideração" as diretrizes antecipadas, bem como "levará em consideração" as "informações" prestadas pelo representante convencional. ${ }^{62}$ Ora, levar em consideração, em terminologia técnico-jurídica, não é o mesmo que estar obrigado pela decisão do paciente. Demais disso, se o paciente elegeu formalmente um representante convencional, em diretrizes antecipadas, tal representante decide em seu nome, não apenas presta informações ao profissional da medicina. Nesse sentido, o texto admite a leitura de que a decisão final, em caso de dúvida ou até de discordância, está nas mãos do profissional da medicina, alijando o paciente, o representante convencional, a família e os demais membros da equipe de saúde (profissionais da enfermagem, psicologia, nutrição, assistência social) do processo.

Em terceiro lugar, a Resolução prevê que o médico “deixará de levar em consideração as diretivas antecipadas de vontade do paciente ou do representante" se, por seu entendimento, elas estiverem em desacordo com o preceituado no Código de Ética Médica. Pois bem, os entendimentos sobre o final de vida e a aceitabilidade de determinados comportamentos, comissivos ou omissivos, são heterogêneos. O Código de Ética Médica não oferece roteiro seguro para tais situações (se o fizesse, desnecessárias seriam as duas Resoluções em comento). Portanto, o enunciado normativo aparenta lançar aos profissionais da medicina um poder de decisão capaz de variar segundo sua leitura do Código de Ética Médica.

Para minimizar o decisionismo médico, poder-se-ia traçar regras em sistema de Procedimento Operacional Padrão ou, ainda, manter intensas as vias de comunicação com outros fóruns de decisão, como a família, equipes multiprofissionais e os Comitês de Bioética Clínica. A Resolução CFM n. 1.995/2012 não parece ter encorajado práticas do estilo. Ao contrário, as vias de diálogo foram estreitadas. A Resolução estipula que as diretrizes antecipadas prevalecem sobre "qualquer outro parecer não médico”, bem como não incentiva a interpretação das próprias diretri-

\footnotetext{
61 Sobre o assunto, verificar Brasil (2014). Ver, também, Lopes Junior (2014).

62 Assim dispõe a Resolução: "Art. $2^{\circ}$ - Nas decisões sobre cuidados e tratamentos de pacientes que se encontram incapazes de comunicar-se, ou de expressar de maneira livre e independente suas vontades, o médico levará em consideração suas diretivas antecipadas de vontade. $\S 1^{\circ}$ - Caso o paciente tenha designado um representante para tal fim, suas informações serão levadas em consideração pelo médico.” (BRASIL, 2012).
} 
zes antecipadas por Comitês de Bioética, tornando-os meros coadjuvantes, com voz apenas nos casos em que não se façam presentes nem as diretrizes antecipadas nem os representantes convencionais, ou naqueles em que não exista consenso entre os familiares. A Resolução pouco instiga os Comitês de Bioética como espaços discursivos privilegiados e com habilidade para construir linhas de conduta (mediante formação de princípios e regras de decisão a partir de casos), de modo que sua atuação no tema se torna subsidiária e as medidas de uniformização - ou o estabelecimento de padrões mínimos de coerência decisória -, enfraquecidas.

Um exemplo pode auxiliar. Suponha-se a seguinte situação: duas pacientes, cada uma em estágio terminal de câncer de mama, diversas metástases, sofrimento intenso, conscientes e capazes. São as pacientes A e B, internadas em diferentes hospitais, em unidades da federação distintas, pelo sistema público de saúde. A paciente A decide, segundo suas convicções religiosas, pela distanásia. Quer que todos os meios ao alcance sejam empregados na manutenção e prolongamento da sua vida, não importa quão dolorosos sejam seus últimos dias. A paciente B, ao contrário, opta exclusivamente pelos paliativos, não quer que qualquer medicamento seja administrado, salvo para controle da dor e do desconforto, nem aceita suporte vital ou alimentação artificial. Também assina uma ordem de não ressuscitação. Suponha-se agora que o profissional da medicina responsável pela paciente A entenda que a distanásia não apenas viola a ética médica por causar sofrimentos excessivos à paciente, como também acredita que mantê-la viva fazendo uso de todos os meios atenta contra a apropriada alocação de escassos recursos da saúde pública. Poderia, com essa base, adotar condutas de ortotanásia? A princípio, não. Porém, a Resolução admite essa interpretação. ${ }^{63}$ Suponha-se que o profissional da medicina responsável pela paciente B tenha uma compreensão deveras estreita da ortotanásia. Poderia administrar outros medicamentos ou promover a ressuscitação da paciente, em caso de parada cardiorrespiratória? A princípio, não. Porém, a Resolução também admite essa interpretação. Uma vez que o texto da Resolução não enuncia mecanismos de cautela nem de uniformização das decisões, as dificuldades tornam-se vigorosas.

As palavras dirigidas à Resolução são duras. Não se pretende sustentar que o CFM tenha procurado instituir a soberania médica em matéria de final de vida, tampouco que tenha pretendido negligenciar a liberdade do paciente e os papéis dos

\footnotetext{
63 O modo de pensar foi veiculado no Congresso Brasileiro de Bioética de 2013, em pôster apresentado por Luísa Allodi Rossit, intitulado Diretrizes antecipadas de vontade e pedidos de tratamento sem potencial de benefício: a nulidade das cláusulas de distanásia. Os autores objetivam "[...] apresentar a conceituação jurídica da manifestação de vontade sobre tratamento médico futuro apreendida sob a forma de diretivas antecipadas de vontade e demonstrar a nulidade de pleno direito das cláusulas de distanásia, à luz da medicina baseada em evidências e da sistemática do ordenamento jurídico brasileiro." O problema de pesquisa é muito relevante e apresenta com nitidez ímpar as ambiguidades e possibilidades interpretativas da Resolução CFM n. 1.995/2012. A preocupação dos pesquisadores estava voltada prioritariamente à ideia de justiça (como tratada pela principiologia da bioética) e a alocação de recursos em saúde. Todavia, permite ver que a escolha pela ortotanásia mediante diretrizes antecipadas pode deixar de ser real, tornando a manifestação da liberdade do paciente uma ficção, substituível por uma decisão eminentemente médica, lastreada em uma mistura de critérios clínicos com concepções de alocação de recursos (ROSSIT et al., 2013, p. 233-234).
} 
familiares e dos demais profissionais da saúde. Pretende-se, tão somente, suscitar o debate acerca de um assunto que precisa de atenção e, provavelmente, de normatização por vias mais sólidas, hábeis a conferir segurança jurídica e maior proteção dos direitos fundamentais. Ideal seria que o poder legislativo retratasse os princípios e os contornos da delegação ao Conselho Federal de Medicina - ou a outras instâncias da Administração Pública.

Não se está sugerindo que os profissionais da medicina não possuam as habilidades técnicas, muito menos que desrespeitem os direitos de seus pacientes. Apenas constata-se que a Resolução CFM n. 1.995/2012 apresenta insuficiências e deficiências relevantes em tema sensível, o direito fundamental à vida. Como aludido, trata-se de direito especial, para o qual se cogita um peso abstrato maior, em hipóteses que envolvem populações muito vulneráveis e, por vezes, invisibilizadas, os pacientes em final de vida. Não se pode esquecer que, há aproximadamente três anos, a ortotanásia era considerada crime no Brasil. Há que pesquisar e refletir sobre se os profissionais da medicina estão efetivamente preparados para essa viragem no trato jurídico com a terminalidade da vida, em todo o vasto e assimétrico território nacional. Há que se refletir, também, sobre a carga jurídica e moral que a Resolução projeta sobre os profissionais da medicina ao dotá-los de papel decisório e interpretativo proeminente.

É certo que a Resolução pode ser interpretada sob sua melhor luz, ao ensejo de normas constitucionais e civilistas e na procura pela integridade do sistema. É certo que podem ser construídos roteiros interpretativos e formulados procedimentos padrões. Todavia, a delicadeza da matéria requer mais. Mais diálogo, mais debate democrático e, especialmente, construção de políticas públicas. Além disso, importante o fortalecimento da educação dos profissionais da saúde para lidar com o final da vida, o aprimoramento dos Comitês de Bioética e dos mecanismos de informação à população. O CFM, com sua atuação normativa, contribuiu; porém, não é o fórum ideal para o desenho democrático e participativo de políticas sobre o final da vida. Considerando-se as suas limitações de alcance normativo subjetivo (apenas os profissionais da medicina) e as suas limitações quanto à delegação normativa, acaba por traçar caminhos inseguros. De tudo, é empenhar-se para que o debate plural avance, pois o que não se deseja, e não se pode admitir, é que o país figure na $38^{\circ}$ posição, entre 40, na qualidade e dignidade da atenção reservada à terminalidade da vida (LOPES JUNIOR, 2014).

\section{Conclusão}

A proposta deste artigo foi elaborar um panorama do direito fundamental à vida, em dimensão vertical, nos estágios recentes do sistema constitucional brasileiro. Para tanto, foram revisadas as posições subjetivas básicas do direito isoladamente. A seguir, foram perscrutados dois elementos medulares da dogmática de aplicação, o alegado caráter absoluto e a propugnada superior hierarquia do direito à vida 
no grupamento dos direitos fundamentais. Verificou-se que o Supremo Tribunal Federal já sinalizava que nenhum direito fundamental ostenta tais características de aplicação, sem estabelecê-lo, contudo, em referência ao direito à vida. Nos últimos cinco anos, em duas decisões marcantes - uma sobre a legitimidade das pesquisas científicas envolvendo células-tronco embrionárias e outra sobre a antecipação terapêutica do parto de fetos portadores de anencefalia - a maioria do Tribunal assentou que o direito fundamental à vida não deve ser tratado como absoluto, tampouco deve ser qualificado com maior hierarquia. Pese embora não ter o STF asseverado que o direito à vida detenha peso abstrato maior, o que lhe confere vantagens em eventual ponderação, sugeriu-se que não apenas há possibilidade de assim aplicá-lo, como também que esta seja a mais adequada forma de fazê-lo, em virtude da sua importância - substantiva e instrumental - e da alta perecibilidade do bem protegido.

Estabelecidas tais premissas, voltou-se a atenção para os problemas de titularidade do direito fundamental à vida, tanto no que se refere aos animais não humanos quanto no que diz com os momentos iniciais do processo de viver humano, ou seja, embriões externos ao útero e embriões e fetos no útero. $\mathrm{Na}$ atual ótica do STF, os animais não humanos não titularizam o direito fundamental à vida, conquanto sejam destinatários de proteção. De acordo com o STF, os embriões preservados fora do útero e os fetos e embriões no útero também não são titulares de direitos, pois a titularidade depende do nascimento com vida. Dessa forma, o Tribunal anuiu à teoria natalista, sem, todavia, selar inteiramente o assunto, pois anunciou que a Constituição Federal apresenta um silêncio proposital, que franqueia opções às vias democráticas, primacialmente a legislativa.

Assumir que determinados entes não titularizam direitos é muito diferente de negar proteção. Os entes em tela - animais não humanos, embriões fora do útero e embriões e fetos no útero - são destinatários de distintos graus de proteção jurídica, forjada mediante instrumentos normativos e sistemas de controle e de fiscalização. Destarte, nenhum se iguala a um bem ou objeto qualquer. Cada um estará sujeito a um cosmos normativo específico que lhe cerca de cuidados, os quais podem ser estabelecidos, a depender das circunstâncias, com restrição de direitos fundamentais alheios. Nesse rumo, o voto do Ministro Relator na ADI n. 3510 aparentou assinalar que haveria uma ordem crescente de proteção, começando pelos embriões criopreservados, seguindo para os embriões e fetos no útero, até desembocar no titular de direitos - a pessoa, o ser humano nascido com vida. Firmar tal interpretação teria sido bastante profícuo ao sistema jurídico, porém, os votos proferidos na ADPF n. 54 admitem leituras em outros sentidos, excludentes entre si, que vão desde a possível titularidade de direitos por um feto viável para a vida extrauterina, até a sugestão de um modelo de qualidade de vida para aferição da titularidade do direito à vida. Nesse aspecto, o método da integridade, a procura de uma coerência principiológica na interpretação dos casos, com enlace entre precedentes à sua melhor luz, seria importante. As decisões estudadas têm ligação, semelhanças e diferenças. Ambas lidam com o trato que o sistema constitucional direciona ao início da vida humana. 
Ora, se na primeira foi dado o firme passo de definir como regente a teoria natalista, na seguinte, não seria de se esperar uma drástica ruptura que levasse à teoria concepcionista ou à da personalidade condicional. $\mathrm{O}$ que manteria a gradação protetiva que se inicia nos embriões fora do útero passa pelo feto e chega, mediante o nascimento com vida, à pessoa.

Em outro polo, quando se raciocina principiologicamente, ventilar um modelo de qualidade de vida é prenhe de significados e consequências, que alcançam outros ângulos, desprendendo-se da específica situação dos fetos portadores de anencefalia, levando à reflexão sobre neonatos acometidos por graves síndromes e também pessoas em final de vida ou em condições absolutamente adversas. Estariam três Ministros do STF oferecendo espaço para uma verdadeira guinada na interpretação dos elementos que conduzem ao reconhecimento e mantêm a titularidade do direito à vida? Em vez de dois parâmetros estáveis, o nascimento com vida aferido pela respiração autônoma e a morte encefálica, girar-se-ia para a verificação de indicadores de qualidade, com esteio nos atributos referidos nos votos? Entende-se que não. Parece não ter sido à toa que o marcador da morte encefálica foi ali inserido - ainda que de modo criticável ao olhar das ciências da saúde. É ele que impede que as ideias de qualidade de vida cogitadas nos votos sejam transpostas para outros momentos e fases da vida humana, como para os pacientes em final de vida. Por conseguinte, para o término da titularidade, mantém-se o viés já tradicional, o critério da morte encefálica.

Para arrematar o sobrevoo acerca do direito fundamental à vida no sistema constitucional brasileiro, investigou-se a outra ponta do espectro, a terminalidade da vida. Tal qual escrito no parágrafo anterior, a partir de determinados níveis de abstração, tornam-se nítidas as justaposições e engates conceituais entre um e outro extremo do arco. Se houvesse vingado um modelo de qualidade de vida nas razões de decidir da ADPF n. 54, diversas poderiam ser as repercussões na compreensão da terminalidade da vida. Frisa-se, o modelo não vingou desvinculado do critério da morte encefálica.

No contexto da terminalidade, houve modificações apreciáveis nos últimos anos. A ortotanásia foi admitida, desde que em pacientes terminais, acometidos de doença incurável mediante consentimento genuíno do titular - hipótese de disposição de posições subjetivas do direito fundamental à vida -, ou autorização de seus responsáveis legais - hipótese de restrição heterônoma do direito fundamental à vida. Seguem vedados o suicídio assistido e a eutanásia. A última novidade está na previsão das diretrizes antecipadas. Introduzidas por meio de Resolução do Conselho Federal de Medicina, ora questionada na íntegra em Ação Civil Pública, as diretrizes antecipadas são objeto de muitos estudos e, também, de críticas, que incidem prioritariamente sobre a maneira pela qual foram inseridas e moldadas as suas regras no sistema brasileiro. Qualquer que seja o resultado final da Ação Civil Pública, não se pode olvidar que a morte com intervenção, no Brasil, está carente de balizadores e de políticas públicas sérias e específicas, construídas mediante o 
crivo democrático e ligadas a mecanismos amplos de operacionalização, pesquisa e fiscalização.

\section{Referências}

ALEXY, Robert. Teoria de los derechos fundamentales. Tradução Ernesto Garzón Valdés. Madrid: Centro de Estudios Constitucionales, 1993.

ARENDT, Hannah. A condição humana. 10. ed. Rio de Janeiro: Forense Universitária, 2004.

BACHOFF, Otto Von. Normas constitucionais inconstitucionais? Coimbra: Almedina, 1994.

BARROSO, Luís Roberto. A dignidade humana no direito constitucional contemporâneo: a construção de um conceito jurídico à luz da jurisprudência mundial. Belo Horizonte: Fórum, 2012.

BARROSO, Luís Roberto. Interpretação e aplicação da constituição: fundamentos de uma dogmática constitucional transformadora. 6. ed. rev., atual. e ampl. São Paulo: Saraiva, 2003.

BARROSO, Luís Roberto; MARTEL, Letícia de Campos Velho. A morte como ela é: dignidade e autonomia no final da vida. $R D E$ - Revista de Direito do Estado, v. 15, p. 27-62, 2010.

BEECHER, Henry K. et al. A definition of irreversible coma. Report of the Ad Hoc Committee of the Harvard Medical School to examine the definition of brain death. JAMA, v. 205, n. 6, p. 85-88 (337-340), Aug. 1968.

BERCOVICCI, Gilberto. O princípio da unidade da constituição. Revista de Informação Legislativa, Brasília, ano 37, n. 145, p. 95-99, jan./abr. 2000.

BEYLEVELD, Deryck; BROWNSWORD, Roger. Consent in the law. Oxford: Hart Publishing, 2007.

BEYLEVELD, Deryck; BROWNSWORD, Roger. Human Dignity in bioethics and biolaw. Oxford: Oxford University press, 2004.

BOBBIO, Norberto. A Era dos Direitos. Rio de Janeiro: Campus, 1992.

BORGES, Jorge Luis. As ruínas circulares. In: BORGES, Jorge Luis. Ficções. Tradução Carlos Nejar. São Paulo: Globo, 1999.

BRASIL. Conselho Federal de Medicina. Resolução n. 1.480/1997, de 08 de agosto de 1997. Brasíla, DF, 08 ago, 1997a. Disponível em: < http://www.portalmedico.org.br/ resolucoes/cfm/1997/1480_1997.htm>. Acesso em: 10 abr. 2014. 
BRASIL. Conselho Federal de Medicina. Resolução n. 1.826/2007, de 06 de dezembro de 2007. Dispõe sobre a legalidade e o caráter ético da suspensão dos procedimentos de suportes terapêuticos quando da determinação de morte encefálica de indivíduo não doador. Brasíla, DF, 06 dez. 2007. Disponível em: <http://www.portalmedico.org.br/resolucoes/cfm/2007/1826_2007.htm>. Acesso em: 10 abr. 2014.

BRASIL. Conselho Federal de Medicina. Resolução n. 1.805/2006, de 28 de novembro de 2006. Na fase terminal de enfermidades graves e incuráveis é permitido ao médico limitar ou suspender procedimentos e tratamentos que prolonguem a vida do doente, garantindo-lhe os cuidados necessários para aliviar os sintomas que levam ao sofrimento, na perspectiva de uma assistência integral, respeitada a vontade do paciente ou de seu representante legal. Brasíla, DF, 28 nov. 2006. Disponível em: < http://www.portalmedico.org.br/resolucoes/CFM/2006/1805_2006.htm>. Acesso em: 12 abr. 2014.

BRASIL. Conselho Federal de Medicina. Resolução n. 1.995/2012, de 31 de agosto de 2012. Dispõe sobre as diretivas antecipadas de vontade dos pacientes. Brasília, DF, 31 ago. 2012. Disponível em: < http://www.portalmedico.org.br/resolucoes/ CFM/2012/1995_2012.pdf>. Acesso em: 15 maio 2014.

BRASIL. Justiça Federal. Seção Judiciária do Estado de Goiás - Primeira vara. Ação Civil Pública n. 1039-86.2013.4.01.3500, de 14 mar. 2013. (Juiz Jesus Crisóstomo de Almeira). Goiânia. Disponível em: < http://www.conjur.com.br/dl/liminar-resolucao-cfm-19952012.pdf>. Acesso em: 14 maio 2014.

BRASIL. Lei n. 8.069, de 13 de julho de 1990. Dispõe sobre o Estatuto da Criança e do Adolescente e dá outras providências. Diário Oficial da União, Brasília, DF, 15 jul. 1990. Disponível em: <http://www.planalto.gov.br/ccivil_03/leis/18069.htm>. Acesso em: 14 maio 2014.

BRASIL. Lei n. 9.434, de 04 fevereiro de 1997. Dispõe sobre a remoção de órgãos, tecidos e partes do corpo humano para fins de transplante e tratamento e dá outras providências. Diário Oficial da União, Brasília, DF, 05 fev. 1997b. Disponível em: <http://www.planalto.gov.br/ccivil_03/leis/19434.htm>. Acesso em: 05 maio 2014.

BRASIL. Lei n. 10.211, de 23 de março de 2001. Altera dispositivos da Lei n. 9.434, de 04 de fevereiro de 1997, que "dispõe sobre a remoção de órgãos, tecidos e partes do corpo humano para fins de transplante e tratamento." Diário Oficial da União, Brasília, DF, 25 mar. 2001. Disponível em: < http://www.planalto.gov.br/ccivil_03/leis/ LEIS_2001/L10211.htm>. Acesso em: 06 maio 2014.

BRASIL. Lei n.10.406, de 10 de janeiro de 2002. Institui o Código Civil. Diário Oficial da União, Brasília, DF, 11 jan. 2002. Disponível em: <http://www.planalto.gov. br/ccivil_03/leis/2002/110406.htm >. Acesso em: 06 maio 2014. 
BRASIL. Ministério Público Federal. Ação Civil Pública n. 2007.34.00.014809-3. Petição Inicial (Wellington Divino Marques de Oliveira - Procurador Regional dos Direitos do Cidadão/1 ${ }^{\text {a }}$ Região). Disponível em: < http://noticias.pgr.mpf.gov.br/noticias-do-site/pdfs/ACP\%20Ortotanasia.pdf > . Acesso em: 15 maio 2014.

BRASIL. Ministério Público Federal. Ação Civil Pública n. 1039-86.2013.4.01.3500. Petição Inicial. (Procurador da República Ailton Benedito de Souza). Procuradoria da República de Goiás, Goiânia, 2013. Disponível em: <http://www.prgo.mpf.mp.br/ images/stories/ascom/ACP-CFM-ortotanasia.pdf > . Acesso em: 15 maio 2014.

BRASIL. Senado Federal. Constituições brasileiras. Brasília: Senado Federal e Ministério da Ciência e Tecnologia, Centro de Estudos Estratégicos, 2001 (Coleção, Constituições Brasileiras, vols. 1 a 7, incluindo 6a).

BRASIL. Supremo Tribunal Federal. Ação Direta de Inconstitucionalidade n. 815-3. Relator: Ministro Moreira Alves. Órgão Julgador: Tribunal Pleno. Julgado em: 10 maio 1996. Publicado em: 28 mar. 1996. Disponível em: <http://stf.jusbrasil.com.br/ jurisprudencia/744338/acao-direta-de-inconstitucionalidade-adi-815-df $>$. Acesso em: 15 maio 2014.

BRASIL. Supremo Tribunal Federal. Ação Direta de Inconstitucionalidade n. 1856. Relator: Ministro Celso de Mello. Órgão Julgador: Tribunal Pleno. Julgada em: 17 nov. 2011. Rio de Janeiro, 29 nov. 2011. Disponível em: <http://www.stf.jus.br/portal/ processo/verProcessoAndamento.asp $?$ numero $=1856 \&$ classe $=$ ADI\&origem $=$ AP $\& \mathrm{r}$ ecurso $=0 \&$ tipoJulgamento $=\mathrm{M}>$. Acesso em: 05 maio 2014 .

BRASIL. Supremo Tribunal Federal. Ação Direta de Inconstitucionalidade n. 2514/ SC. Relator: Ministro Eros Grau. Órgão Julgador: Tribunal Pleno. Julgada em: 29 jun. 2005. Publicada em: 29 jun. 2005. Brasília, DF. Disponível em: <http://redir.stf. jus.br/paginadorpub/paginador.jsp?docTP $=\mathrm{AC} \&$ docID $=266833>$. Acesso em: 15 maio 2014.

BRASIL. Supremo Tribunal Federal. Ação Direta de Inconstitucionalidade n. 3776/ $R N$. Relator: Ministro Cezar Peluso. Órgão Julgador: Tribunal Pleno. Julgada em: 14 jun. 2007. Publicada em: 29 jun. 2007. Disponível em: <http://stf.jusbrasil.com. br/jurisprudencia/14728208/acao-direta-de-inconstitucionalidade-adi-3776-rn>. Acesso em: 15 maio 2014.

BRASIL. Supremo Tribunal Federal. Ação Direta de Inconstitucionalidade n. 3510/ DF. Relator: Ministro Ayres Britto. Órgão julgador: Tribunal Pleno. Julgamento em: 29 maio 2008. Publicado em: 28 maio 2010. Disponível em: <http://www.stf.jus. $\mathrm{br} /$ portal/geral/verPdfPaginado.asp $? \mathrm{id}=611723 \&$ tipo $=\mathrm{AC} \&$ descricao $=$ Inteiro $\% 20$ Teor\%20ADI\%20/\%203510 >. Acesso em: 05 jun. 2014. 
BRASIL. Supremo Tribunal Federal. Arguição de Descumprimento de Preceito Fundamental n. 54/DF. Relator: Ministro Marco Aurélio. Julgado em: 12 abr. 2012. Brasília, DF, 2012. Disponível em: < http://redir.stf.jus.br/paginadorpub/paginador. jsp?docTP=TP\&docID=3707334>. Acesso em: 06 jun. 2014.

BRASIL, Supremo Tribunal Federal. Arguição de Descumprimento de Preceito Fundamental n. 130-7. Relator: Ministro Carlos Britto. Julgado em: 07 nov. 2008. Publicado em: 06 nov. 2009. Brasília, DF, 2009. Disponível em: < http://redir.stf.jus.br/paginadorpub/paginador.jsp?docTP=AC\&docID=605411>. Acesso em: 06 jun. 2014 .

BRASIL. Supremo Tribunal Federal. Mandado de Segurança n. 23.452. Relator: Ministro Celso de Mello. Órgão Julgador: Tribunal Pleno. Julgado em: 16 set. 1999. JusBrasil, Rio de Janeiro, 12 maio 2000. Disponível em: < http://stf.jusbrasil.com.br/ jurisprudencia/738746/mandado-de-seguranca-ms-23452-rj >. Acesso em: 05 maio 2014.

BRASIL. Supremo Tribunal Federal. Recurso Extraordinário n. 153.531-8/SC. Relator: Ministro Francisco Rezek. Redator para o Acórdão: Ministro Marco Aurélio. Órgão Julgador: Segunda Turma. Julgado em: 03 jun. 1997. Disponível em: < http:// redir.stf.jus.br/paginadorpub/paginador.jsp?docTP $=\mathrm{AC} \&$ docID $=211500>$. Acesso em: 15 jun. 2014.

BRASIL. Supremo Tribunal Federal. Recurso Extraordinário n. 179.485/AM. Relator: Ministro Marco Aurélio Mello. Órgão Julgador: Segunda Turma. Julgado em: 06 dez. 1994. Disponível em: <http://www.stf.jus.br/portal/geral/verPdfPaginado. asp $? \mathrm{id}=224535 \&$ tipo $=$ AC\&descricao $=$ Inteiro\%20Teor\%20RE\%20/\%20179485> Acesso em: 05 maio 2014.

BRASIL. Supremo Tribunal Federal. Recurso Extraordinário n. 494601/RS. Relator: Ministro Marco Aurelio. Julgado em: 14 jun. 2012. Disponível em: < http://www.stf. jus.br/portal/processo/verProcessoAndamento.asp?incidente $=2419108>$. Acesso em: 15 maio 2014.

BRASIL. Supremo Tribunal de Justiça. Habeas Corpus n. 56.572. Relator: Ministro Arnaldo Esteves de Lima. Órgão Julgador: Quinta Turma. Julgado em: 15 maio 2006. JusBrasil, São Paulo, 15 maio 2006.

BRASIL. Supremo Tribunal de Justiça. Recurso Especial n. 937.310/SP. Relator: Ministro Luiz Fux. Órgão Julgador: Primeira Turma. Julgado em: 09 dez. 2008. Publicado em: 19 fev. 2009. Disponível em: < http://stj.jusbrasil.com.br/ jurisprudencia/2439595/recurso-especial-resp-937310-sp-2007-0060029-4/inteiro-teor-12218722>. Acesso em: 15 maio 2014.

BROCK, Dan. Life and death: philosophical essays in biomedical ethics. Cambridge: Cambridge University Press, 2000. 
BUCHANAN, Allen. Advance directives and the personal identity problem. Philosophy and public affairs, v. 17, n. 4, p. 277-302, Autumn 1988.

BULOS, Uadi Lammêgo. Curso de direito constitucional. São Paulo: Saraiva, 2007.

CANOTILHO, José Joaquim. Direito constitucional e teoria da constituição. Coimbra: Almedina, [entre 1997 e 2012].

CHUECA, Ricardo Rodríguez. El marco constitucional del final de la própria vida. Revista Española de Derecho Constitucional, n. 85, p. 99-123, enero/abr. 2009.

CLÈVE, Clèmerson Merlin; FREIRE, Alexandre. Direitos Fundamentais e Jurisdição Constitucional. São Paulo: Thomson Reuters, 2014.

COGGON, John. Could the right to die with dignity represent a new right to die in English law? Medical Law Review, n. 14, p. 223-226, Summer 2006.

COMPARATO, Fábio Konder. A afirmação histórica dos direitos humanos. 3. ed. São Paulo: Saraiva, 2003.

DEGRAZIA, David. Identity, killing and the boundaries of our existence. Philosophy and Public Affairs, v. 31, n. 4, p. 413, 2003.

DINIZ, Débora. Quando a morte é um ato de cuidado: obstinação terapêutica em crianças. Cadernos de Saúde Pública, v. 22, n. 8, p. 1741-1748, ago. 2006.

DOWBIGGIN, Ian Robert. A concise history of euthanasia: life, death, god and medicine. Lanham: Rowman \& Littlefield, 2005.

DWORKIN, Ronald. O domínio da vida: aborto, eutanásia e liberdades individuais. São Paulo: Martins Fontes, 2003.

EUROPEAN COURT OF HUMAN RIGHTS. Case of Pretty v. United Kingdom. Strasbourg, 29 Apr. 2002. Disponível em: <http://hudoc.echr.coe.int/sites/eng/pages/ search.aspx? $i=001-60448 \#\{$ “itemid":[“001-60448”] $\}>$. Acesso em: 15 jun. 2014.

FEINBERG, Joel. Rights, justice and the bounds of liberty: essays on social philosophy. Princenton: Princenton University, 1980.

FEINBERG, Joel. Voluntary euthanasia and the inalienable right to life. The Tanner Lectures on Human Values, p. 224, 1997. Disponível em: < http://www.tannerlectures.utah.edu/lectures/feinberg80.pdf>. Acesso em: 15 maio 2014.

GARNER, Bryan A. (Ed.). Black's Law Dictionary. 8. ed. Thomson West, 2004.

GHERARDI, Carlos R. La muerte intervenida: uma visón comprensiva desde la acción sobre el soporte vital. Perspectivas Bioéticas, v. 11, n. 20, p. 102-121, 2006. 
HÄBERLE, Peter. La liberdad fundamental en el Estado constitucional. Peru: Fondo Editorial de la Pontifícia Universidad Católica del Perú, 1997.

HOHFELD, Wesley Newcomb. Fundamental legal conceptions as applied in judicial reasoning. New Jersey: The Law Book Exchange, 2000.

HOLMES, Stephen; SUNSTEIN, Cass R. The Cost of Rights: why liberty depends on taxes. New York: W. W. Nortton \& Company, 2000.

JONAS, Hans. The right to die. The hasting Center Report, v. 8, n. 4, p. 31-36, Aug. 1978.

KASS, Leon R. Is there a right to die? The Hastings Center Report, v. 23, Jan./Feb. 1993.

KEOWN, John. European Court of Human Rights: Death in Strasburg - assisted suicide, the Pretty case, and the European Convention on Human Rights. International Journal of Constitutional Law, n. 1, 2003.

LÓPEZ, Eduardo Rivera. Ética y trasplantes de órganos. México: UNAM/FCE, 2001.

LOPES JUNIOR, Dalmir. A eutanásia e os direitos do paciente: uma análise da realidade normativa da Bélgica e do Brasil. Mímeo. In: IACOMINI, Vanessa; LOPES JUNIOR, Dalmir (Org.). Bioética e Biodireito: fim de vida. Curitiba: Juruá, 2014.

MARSHALL, Thomas Humprey. Classe, cidadania e status. Rio de Janeiro: Zahar, 1967.

MARTEL, Letícia de Campos Velho. Hierarquização de direitos fundamentais: a doutrina da posição preferencial na jurisprudência da Suprema Corte norte-americana. Sequência, Florianópolis, v. 48, n. 25, p. 91-117, 2004.

MARTEL, Letícia de Campos Velho: Direitos Fundamentais indisponíveis: limites e padrões do consentimento para a autolimitação do direito à vida. Rio de Janeiro: Tese (Doutorado em Direito Público)-Universidade Estadual do Rio de Janeiro, 2010. Disponível em: < http://works.bepress.com/leticia_martel/5/>. Acesso em: 15 jun. 2014.

MCCONNELL, Terrance. Inalienable Rights - the limits of consent in medicine and the law. Oxford: Oxford University Press, 2000.

MEDICAL LAW REVIEW. Oxford: Oxford University Press, v. 9, n. 3, p. 201-298, Autumm 2001.

MENDES, Gilmar Ferreira et al. Curso de direito constitucional. São Paulo: Saraiva; Brasília: IDP, 2007. 
NEVARES, Ana Luiza Maia. Apontamentos sobre o direito de testar. In: PEREIRA, Tania da Silva et al. Vida, morte e dignidade humana. Rio de Janeiro: GZ, 2010.

NOVAIS, Jorge Reis. As restrições aos direitos fundamentais não expressamente autorizadas pela Constituição. Coimbra: Almedina, 2003.

NUSSBAUM, Martha; SUNSTEIN, Cass. Animal Rights: current debates and new directions. Oxford: Oxford University, 2004.

OLIVEIRA, Cláudio Ladeira de. Ativismo judicial, moderação e o minimalismo de Cass Sunstein. CONGRESSO NACIONAL DE PESQUISA E PÓS-GRADUAÇÃO EM DIREITO, 16., 2007, Campos dos Goytacazes. Anais... Campo dos Goytacazes, 2007. Disponível em: < http://www.conpedi.org.br/manaus/arquivos/anais/campos/ claudio_ladeira_de_oliveira.pdf $>$. Acesso em: 05 jun. 2014.

ORO, Ari Pedro. The sacrifice of animals in afro-brazilian religions: analysis of a recent controversy in the Brazilian state of Rio Grande do Sul. Tradução: Enrique Julio Romera. Relig. Soc., v. 1, 2006. Disponível em:

$<$ http://socialsciences.scielo.org/scielo.php?script =sci_arttext\&pid=S0100$-85872006000100001 \& \operatorname{lng}=$ en\&nrm $=$ iso $>$. Acesso em: 15 jun. 2014.

PACHECO, Cláudio. Tratado das Constituições brasileiras. Rio de Janeiro: Freitas Bastos, 1958-1965.

PEREIRA, Jane Reis Gonçalves. Interpretação constitucional e direitos fundamentais. Rio de Janeiro: Renovar, 2006.

RAMOS, André de Carvalho. Manual prático de direitos humanos internacionais. Brasília: Escola do Ministério Público da União, 2009.

REGAN, Tom. The case for animal rights. California: University of California Press, 2004.

RIBEIRO, Diaulas Costa. Um novo testamento: testamentos vitais e diretivas avançadas antecipadas. In: PEREIRA, Rodrigo da Cunha (Org.). Família e dignidade humana. São Paulo: IOB Thompson, 2006.

RIO GRANDE DO SUL (Estado). Assembleia Legislativa. Lei n. 12.131/04, de 23 de julho de 2004. Disponível em: <www.alergs.gov.br>. Acesso em: 06 jun. 2014.

RIO GRANDE DO SUL (Estado). Tribunal de Justiça. Ação Direta de Inconstitucionalidade n. 70010129690. Relator: Paulo de Tarso Vieira Sanseverino. Órgão Julgador: Tribunal Pleno. Julgado em: 13 abr. 2009. Disponível em: <www.mp.rs. gov.br/areas/ambiente/arquivos/adin_culto.doc >. Acesso em: 06 jun. 2014. 
RIO GRANDE DO SUL (Estado). Tribunal de Justiça. Ação Direta de Inconstitucionalidade n. 70010129690. Relator: Desembargador Araken de Assis. Órgão Julgador: Tribunal Pleno. Julgado em: 18 abr. 2005. Publicado em: 17 ago. 2005. Disponível em: <http://tj-rs.jusbrasil.com.br/jurisprudencia/7875033/acao-direta-de-inconstitucionalidade-adi-70010129690-rs >. Acesso em: 15 maio 2014.

RIO GRANDE DO SUL (Estado). Tribunal de Justiça. Agravo de Instrumento n. 70000411686. Relator: Fabianne Breton Baisch. Órgão Julgador: Primeira Câmara Cível. Julgado em: 07 ago. 2000.

ROSSIT, Luisa Allodi et al. Diretivas antecipadas de vontade e pedidos de tratamento sem potencial benefício: a nulidade das cláusulas de distanásia. Revista Brasileira de Bioética, v. 9, p. 233-234, 2003.

SÁ, Maria de Fátima Freire de. Direito de morrer: eutanásia e suicídio assistido. Belo Horizonte: Del Rey, 2001.

SÁ, Maria de Fátima Freire de; PONTES, Maíla Mello Campolina. Autonomia Privada e Biodireito: Podemos, legitimamente, pensar em um direito de morrer? Revista Jurídica UNIJUS, v. 11, p. 177-192, 2008.

SARLET, Ingo Wolfgang. A eficácia dos direitos fundamentais. Porto Alegre: Livraria do Advogado, 2001.

SARMENTO, Daniel. Ponderação de interesses na Constituição Federal. Rio de Janeiro: Lumen Juris, 2000.

SCHREIBER, Simone. Publicidade opressiva de julgamentos criminais. Rio de Janeiro: Renovar, 2008.

SCHRAMM, Fermin Roland. O uso problemático do conceito 'vida' em bioética e suas interfaces com a práxis biopolítica e os dispositivos de biopoder. Revista Bioética, v. 17, n. 3, p. 377-389, 2009.

SCHWARTZ, Bernard. Os grandes direitos da humanidade: the Bill of Rights. Rio de Janeiro: Forense Universitária, 1979.

SERNA, Pedro; TOLLER, Fernando. La interpretación constitucional de los derechos fundamentales: una alternativa a los conflictos de derechos. Buenos Aires: La Ley, 2000.

SILVA, Virgílio Afonso da. A constitucionalização do direito: os direitos fundamentais nas relações entre particulares. São Paulo: Malheiros, 2005.

SINGER, Peter. Ética prática. 3. ed. São Paulo: Martins Fontes, 2002.

SINGER, Peter. Sanctity of life or quality of life? Pediatrics, v. 72, n. 1, July 1983. 
STANFORD ENCYCLOPEDIA OF PHILOSOPHY. Supererogation. 2002. Disponível em: <http://plato.stanford.edu/entries/supererogation/>. Acesso em: 06 jun. 2014.

SUNSTEIN, Cass. One Case at Time: judicial minimalism on the Supreme Court. Cambridge: Oxford University Press, 1999.

TEIXEIRA, Ana Carolina Brochado; PENALVA, Luciana Dadauto. Terminalidade e autonomia: uma abordagem do testamento vital no direito brasileiro. In: PEREIRA, Tania da Silva et al. Vida, morte e dignidade humana. Rio de Janeiro: GZ, 2010.

THE CHARTERS OF FREEDOM. Bill of Rights. 1791. Disponível em: <www.archives.gov/exhibits/charters/bill_of_rights.html>. Acesso em: 20 jun. 2014.

THE CHARTERS OF FREEDOM. The Virginia Declaration of Rights. 1776. Disponível em: <www.archives.gov/exhibits/charters/virginia_declaration_of_rights. html >. Acesso em: 20 jun. 2014.

THOMSON, Judith Jarvis. The realm of rights. Cambridge: Harvard University Press, 1990.

TRIBE, Laurence H.; DORF, Michael C. On reading the Constitution. Cambridge: Harvard University, 1991.

YORK, John. Introduction: The right to life and the value of life: orientations in law, politics and ethics. In: YORK, John. The right to life and the value of life: orientations in law, politics and ethics. Surrey, England: Ashgate Publishing, 2010.

Data da submissão: 09 de março de 2015

Aceito em: 11 de abril de 2015 
